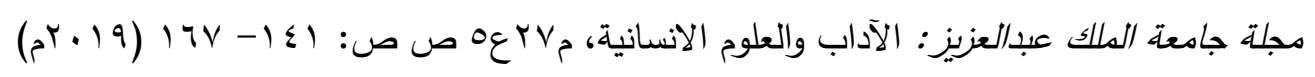

DOI:10.4197/Art.27-5.6

\title{
مفاهيم التدريب وأساليبه في تعليم اللغة العربية
}

\author{
د. نوح بن يحيى الثهري \\ عضو هيئة التدربس بقسم اللغة العربية \\ بجامعة الملك عبد العزيز
}

مستخلص. تناول الباحث في بحثه هذا مفاهيم التدريب وأساليبه التي يمكننا استخدامها في تعليم اللغة العربية، وذلك من خلال تطرقه لما تميّز به علم النحو من دور وظيفي ينمي المهارات اللغوية، وبيان موضع العلم بين الرسالة

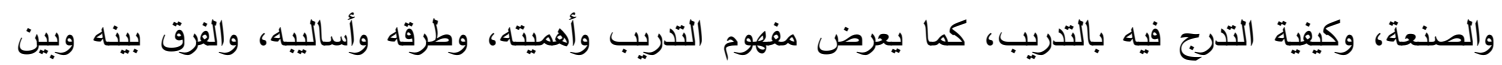
التعليم، مبيناً شيئاً من نماذج استخدم العلماء الأوائل لأساليب تدريبية، ويعزّج على التدريب على التهائه المهارات اللغوية، ذاكراً تجربته في تدريس مادة (التدريب العملي) لطلاب جامعة الملك عبد العزيز ، وأهداف هذه المادة ومحاورها، وكيفية تثييم الطالب من خلال هذه المحاور ، واختتم البحث بخاتمة مجملة ثم التوصيات.

القصوى، والمكانة العظمى؛ إذ بإدراك كنه هذه اللغة

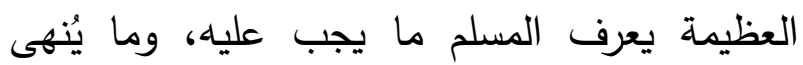

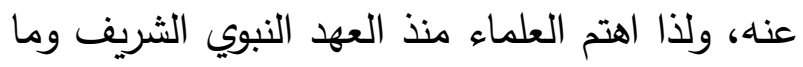

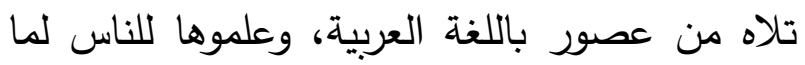

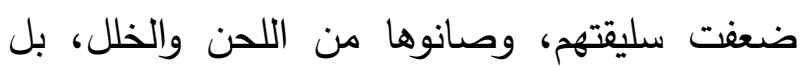

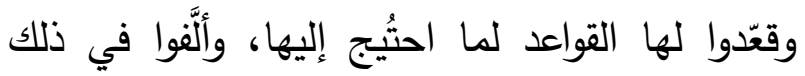

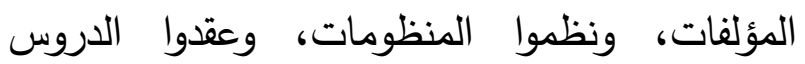

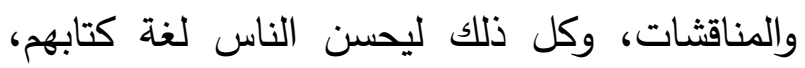

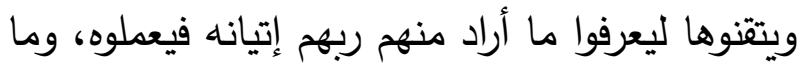
أراد منهم تركه فيجتنبوه.

\section{المقدمة}

الحمد لله والصلاة والسلام على رسول الله وعلى آله وصحبه ومن والاه وبعد فإن اللغة العربية أقوى اللغات قاطبة، وأكثرها

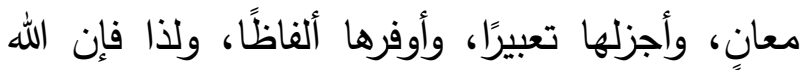

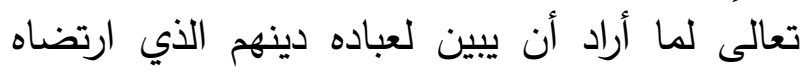

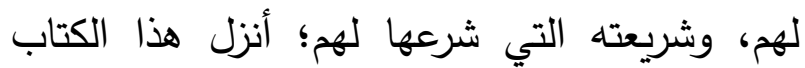

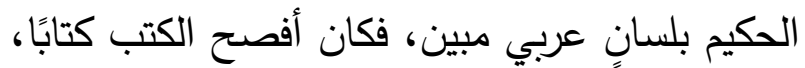
وأكثرها إعجازًا، وأوضحها بيانًا. ومن هنا كان لتعلم اللغة العربية الأهمية 
العربية في الصفوف الثلاثة الأولى من المرحلة الابتدائية من وجهة نظر عينتي الإلتية الدراسة"، رسالة علمية مقدمة لكلية التربية بجامعة أم القرى، للباحث

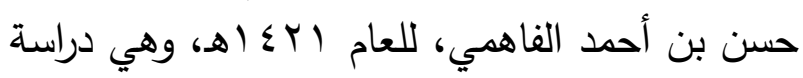

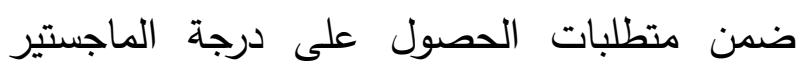

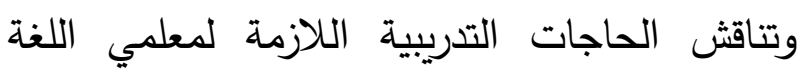
العربية في الصفوف الثلاثة الأولى من المرحلة

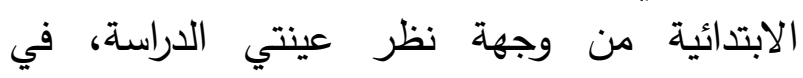

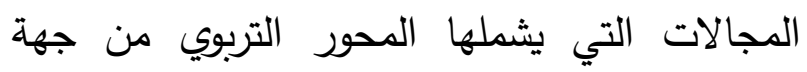

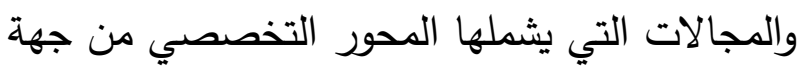
ثانية، من وجهة نظر كل من مشرفي اللغة العربية

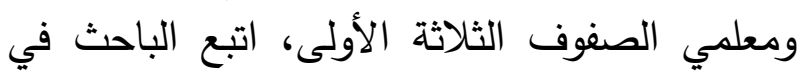

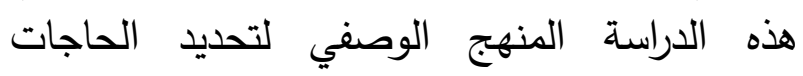

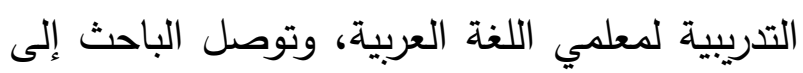

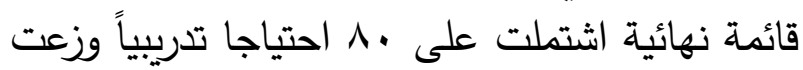

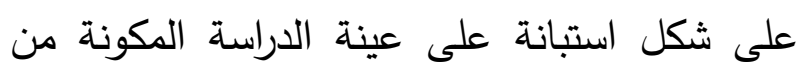

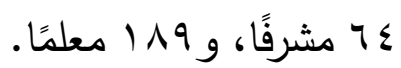

ومن النتائج: التوصل إلى قدئا. قائمة بالحاجات

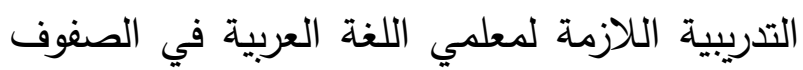

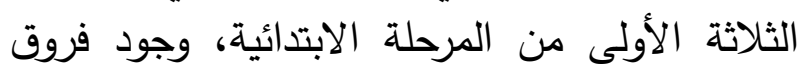

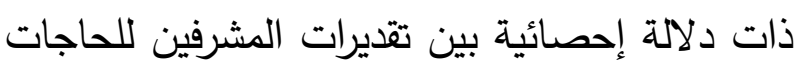

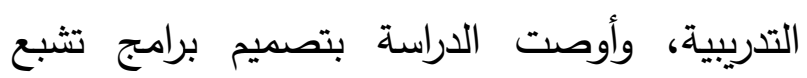

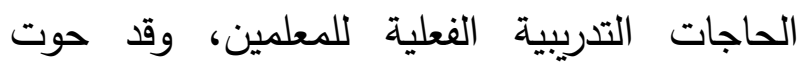

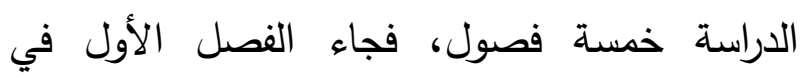

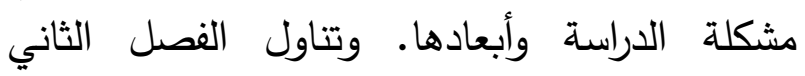
الإطار النظري والدراسات السابقة، أولاً التدريب أثناء

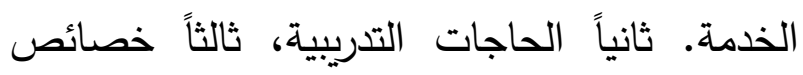

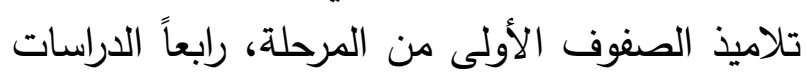

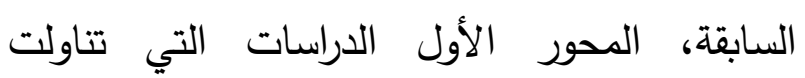

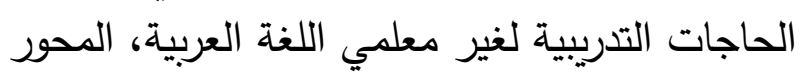
الثاني الدراسات التي تتاولت الحاجات التدريبية
ومما لا شك فيه أن الأساليب والطرق هامة في العملية التعليمية؛ إذ بها يتم وصول المعلون الاسلومة للمتلقي

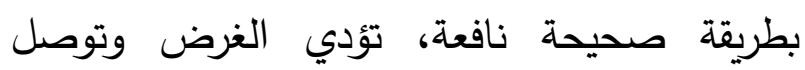
لللهدف.

ولما كانت الذُربة على أي عمل أو نشاط هي

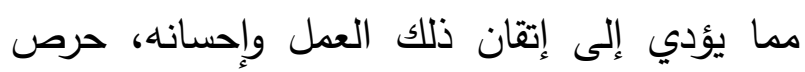
الناس على ذلك، وكانت الذُربة طريقًا للتعلم والتلقي التياني والإتقان. وهذا البحث يفتح هذا المجال باستخدام التدريب

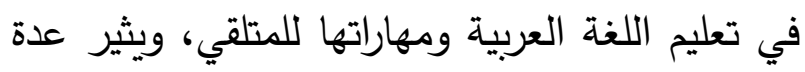
نقاط في هذا الجانب حتى تكون مفاتيح للبحث بصورة أوسع، وتطبيقا التدريب في تعليم اللغة العربية

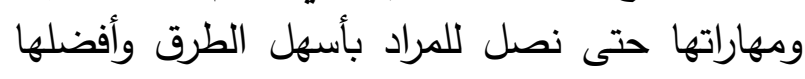

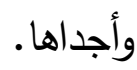

\section{مشكلة الاراسة}

تكمن مشكلة الدراسة في كيفية الاستفادة من الإلية

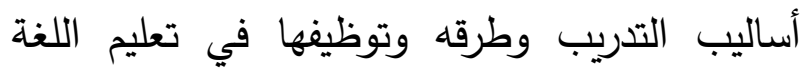

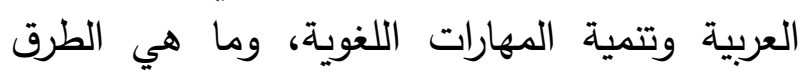
الملائمة والفعالة لتحقيق هذا الهدف.

\section{أهداف البحث}

() بيان أثر علم النحو في تتمية المهارات اللغوية.

r) توضيح مفهوم التدريب وأهميته، وأبرز طرقه وأساليبه.

r) إبراز أثر التدريب في تعليم اللغة العربية ومهاراتها، وأهم الطرق والأساليب الناجعة في تحقيق ذلك.

\section{الدراسات السابقة}

() "الحاجات التدريبية اللازمة لـعلمي اللغة 
قدمها الباحثتان أسماء عزيز عبد الكريم وإقبال كاظم حبيتر لمجلة الآداب بجامعة الكوفة بالعراق في العدد

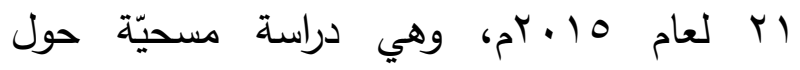
الموضوع، وتبيّن هذه الدراسة ما يحتاجه معلمو ومعلمات اللغة العربية بالعراق من مهارات تدرببية، ونئ، واستخدمت الباحثتان فيه المنهج الوصفي، وتحددت بعنه عينة الدراسة في (9191) معلمًا ومعلمة للغة العربية في منطقة الفرات الأوسط بجمهورية العراق للمرحلة

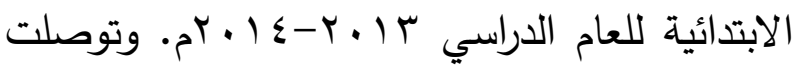
الباحثتان إلى مجموعة من الاقتراحات والتوصيات، منها: استخدام التقنيات الحديثة في التدريب، وقد اشتملت الدراسة على أربعة فصول؛ في الفصل الأول مشكلة البحث، وأهميته، وأهدافه، وفرضياته،

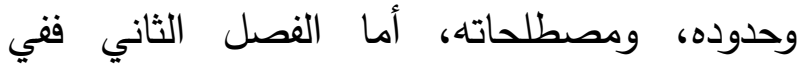
الإطار النظري، والدراسات السابقة، وكان الفصل ولتهل الثالث في إجراءات البحث، وتطرق الفصل الرابع لعرض النتائج وتفسيرها، ثم الاستنتاجات والتوصيات والمقترحات، ثم ملخص البحث، وقائمة المصادر والمراجع.

وجميع هذه الدراسات جيدة ومفيدة، إلا أنها تعرض المسألة من وجهة نظر المعلمين والمعلمات، لا من وجهة نظر المدربين، وهذا ما يتميز باه هذا البحث عنها؛ إذ يعرض المسألة من وجهة نظه نظر المدربين، وأعتقد أن المدرب أدرى بالتدريب وأساليبه وطرقه الملائمة وكيفية الاستفادة منها من المعلمين.

\section{المنهج}

استخدم الباحث في بحثه هذا المنهج الوصفي التجريبي، وذلك من خلال خبرته في تدريس اللغة العربية بجامعة الملك عبد العزيز ، وخبرته أيضًا في مجال التدريب، وتجربته بتدري مادة (التدريب العملي) بالجامعة، وقد احتوى البحث على المباحث
لمعلمي اللغة العربية، واستعرض الفصل الثالث إجراءات الدراسة. وقدم الفصل الرابع تحليل النتائج وتفسيرها، وعاين الفصل الخامس ملخص نتائج الدراسة، ثم توصيات الدراسة، ومقترحاتها، وقائمة

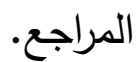
r) "الحاجات التدربيية اللازمة لمعلمات اللغة العربية في مجال اكتشاف التلميذات الموهوبات لغويًا ورعايتهن بالعاصمة المقدسة"، للباحثة أربج بنت

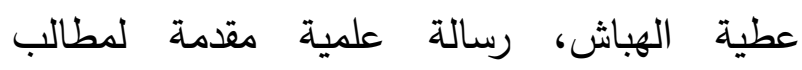
الحصول على درجة الماجستير في المناهج وطرق

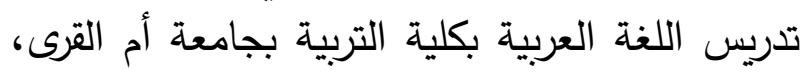

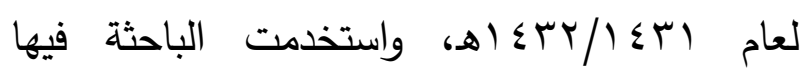
المنهج الوصفي، وتحددت عينة الدراسة في معلمات اللغة العربية في مراحل التعليم العام (الابتدائية والمتوسطة والثانوية) بالعاصمة المقدسة، وتكونت

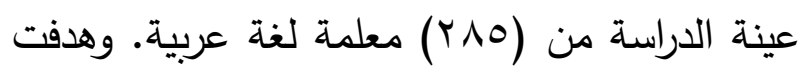
الدراسة إلى تحديد الاحتياجات التدربيية اللازمة لمعلمات اللغة العربية في مجال اكتشاف التلميذات الموهوبات لغويا، ومن النتائج: التوصل إلى (IV) حاجة تدريبية لازمة لمعلمات اللغة العربية في مجال اكتشاف التلميذات الموهوبات لغويا، و(ب0) حاجة تدربيية لازمة لمعلمات اللغة العربية في مجال رعاية التلميذات الموهوبات لغويا. وقد اشتملت الدراسة على خمسة فصول؛ ففي الأول مشكلة الدراسة وأبعادها، وفي الفصل الثاني الخلفية النظري، أما الفصل الثالث ففي إجراءات الدراسة الميدانية، وكان الفصل الرابع في نتائج الدراسة ومناقشتها، وتعرضت الباحثة في الفصل الخامس إلى ملخص الدراسة وتوصياتها ومقترحاتها، ثم قائمة المصادر والمراجع.

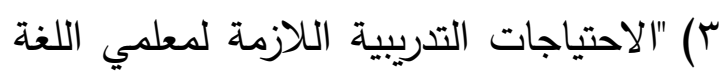
العربية ومعلماتها من وجهة نظهرهم"، وهي دراسة 
لتلك المشكلة؛ ومن ثََّّ الإبداع في ابتكار الحلول

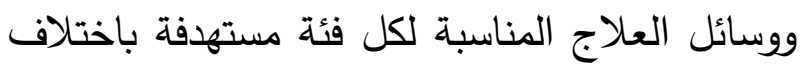

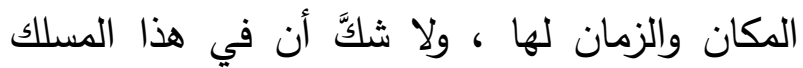

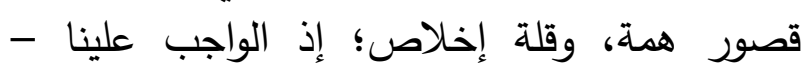

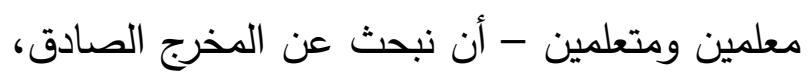

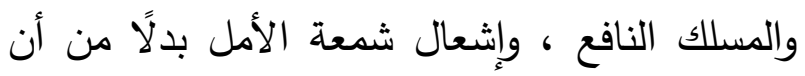

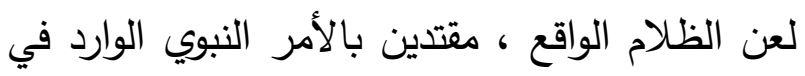

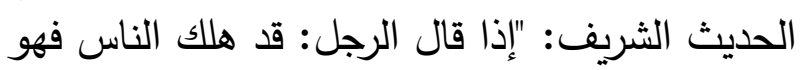

$$
\text { أهلكهم (') (1)". }
$$

ومن هذا المنطلق فإن هناك أسبابًا عديدةً

أسهرت في ضعف تعليم اللغة العربية (r) ؛ لعل من البان

$$
\text { أبرزها : }
$$

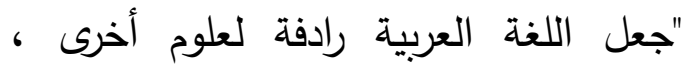

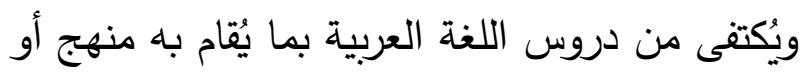

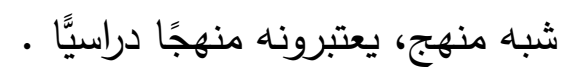

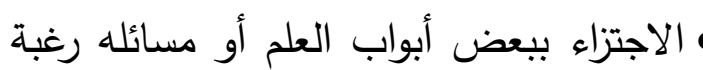

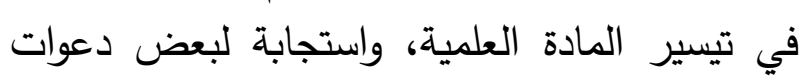

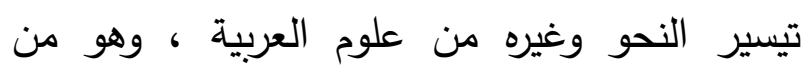

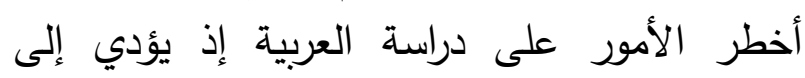
قصور في تصور المادة .

• ظاهرة المذكرات والأمالي الجامعية، بلُغَتِها

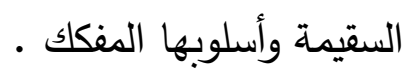

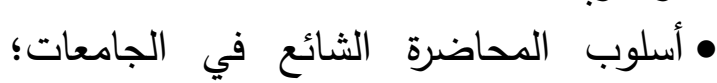
فاللغة بدون تتمية المدارك التي وراء القواعد، أو الجاتي الذوق الذي يجاوز النصوص عملية غثة باردة بل وخيمة ثقيلة، تصد الدارس وتقطع السبيل عليه، كما لئل

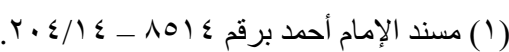

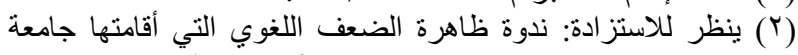

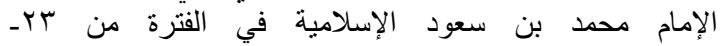

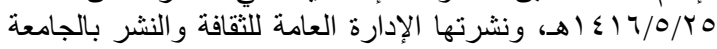

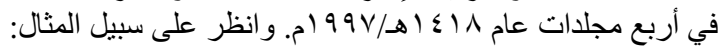

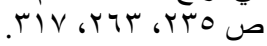

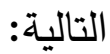

- - تمهيد في أزمة اللغة العربية مع متعلميها. - التعليم بين الرسالة والصنعة. - - التدرج في التعليم من طرق التدريب. - التدريب مفهومه وأهميته. -

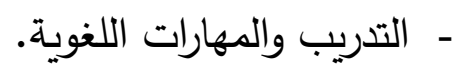

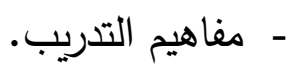
- مفهوم تحديد الاحتياجات التدريبية.

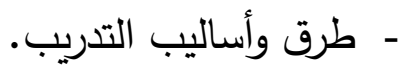
- تجربة ذاتية في تدريس مادة (التدريب

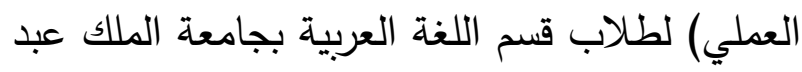

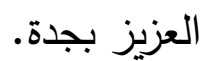

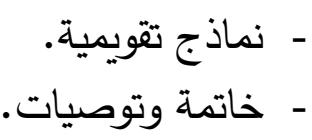

\section{تمهيد}

تعيش اللغة العربية مع أبنائها أزمة حقيقية في تئل

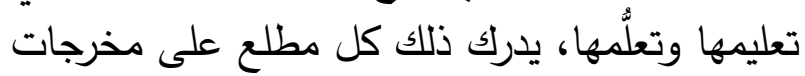

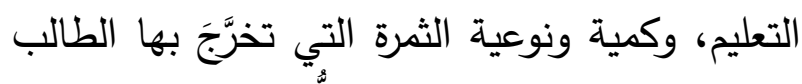
بعد عمر ليس بالقصير في تعلُم اللغة العربية، وما يلحق ذلك من الآثار العلمية على الواقع اللغوي.

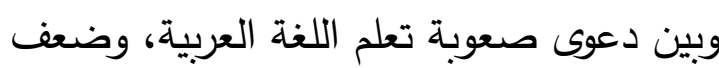

مستوى الطالب، وعجز بعض المعلمين عن إيصالها

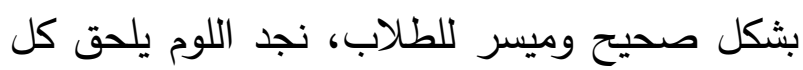

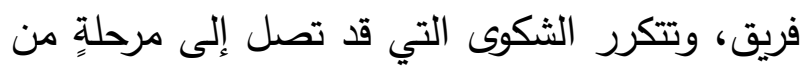

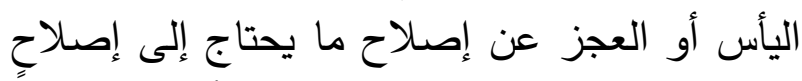

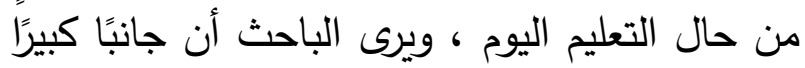

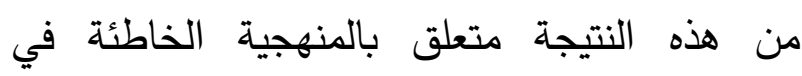

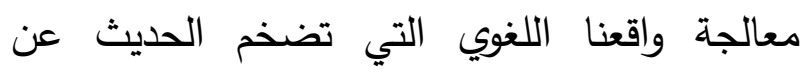
المظاهر والآثار لتجعله مبررا للعجز والقعود ، ودليلًا

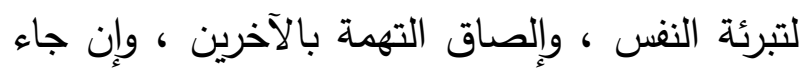
هذا على حساب التركيز لمعرفة الأسباب الحقيقية والهين 
واللحن عادتنا)(汭

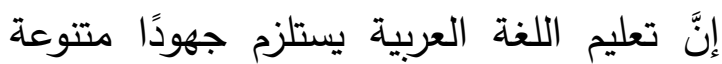

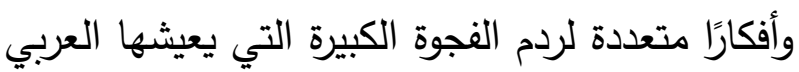

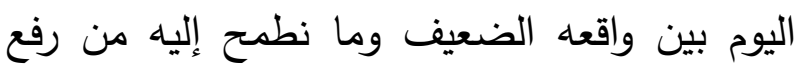
راية العببية وإظهار محاسنها ومعجزاتها؛ فهي معجزة الئه

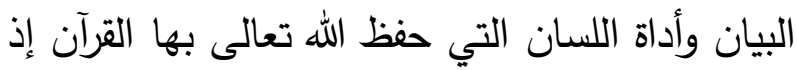

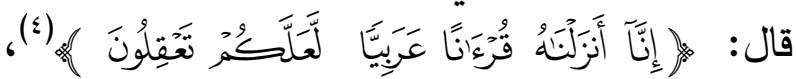

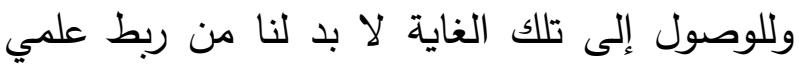

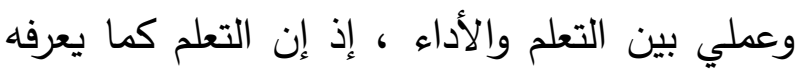

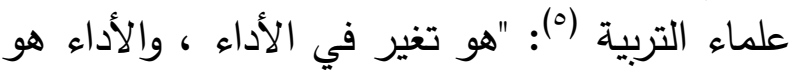

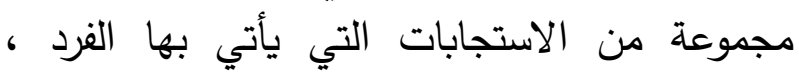

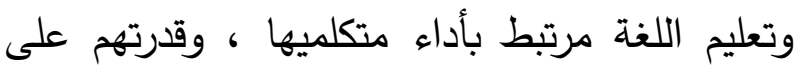
تطبيق ما تعلموه من نظريات ومهارات ، ومن هنا هنا

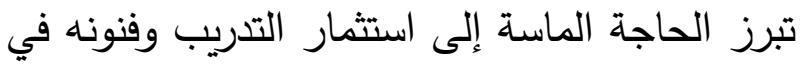

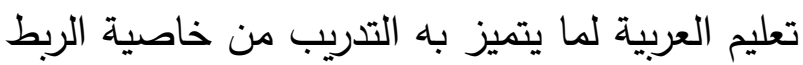
بين التعلم والأداء . تعلمبيم يقول مالك جش في تعليم التعلم: "إنَّهَ تغير في

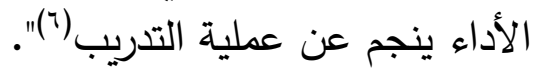
والتدريب بمفاهيمه المتعددة وأساليبه المتنوعة

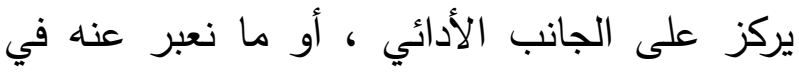
اللغة العربية بالمهارات أو الكفايات ، وهي لبُّ اللغة الته

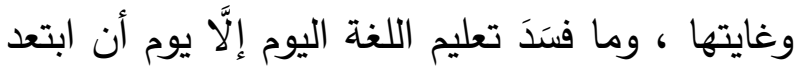

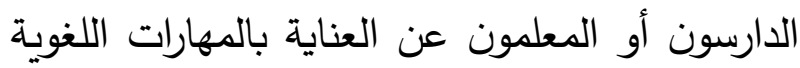

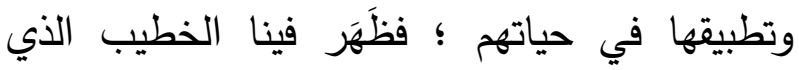
يلحن في خطبته ، والكاتب الذي يخطئ في أبجديات الإملاء ، والقارئ الذي لا يتمكن من إقامة سطرِ أو

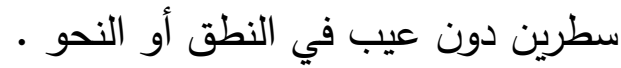

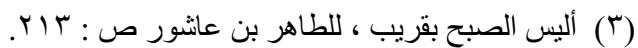

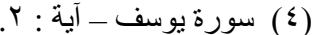
(0) ينظر التعليم أسسه ومناهجه ونظرياته ، لأحمد زكي صالح ص : $\varepsilon r$ (7 (7 علم النفس و التعلم ، حسن حافظ وآخرون
أنها بدون الجانب التطبيقي قليلة الجدوى(')".

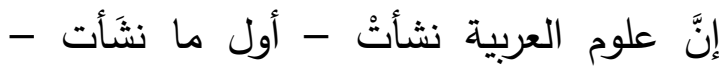
لتقويم اللسان، وتتمية الملكة البيانية، "واجتهد العلماء

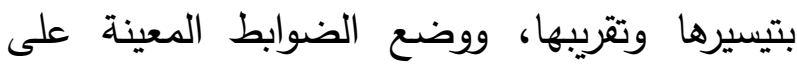
تكوين الملكة، غير أنه لما طال بالناس الأمد انقلبـت فئن الوسائل فصارت غايات؛ فالعناية بتكوين الملكة نُسيتُ، وسيطرت المعايير والتوانين التي انتهى إليها أهل العربية على جميع دروس العربية ، وكأنما

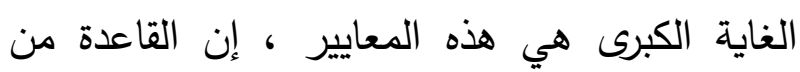

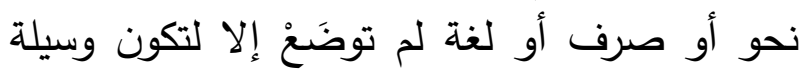

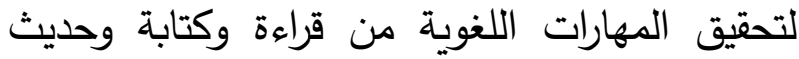

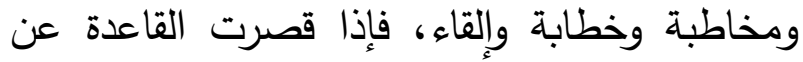
تحقيق هذه المهارات فلا طائل من تعلمها إلا شغل

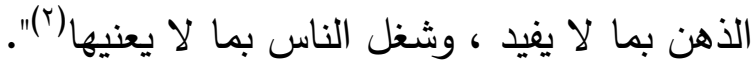

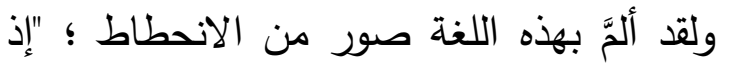

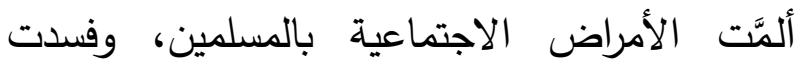
الملكات بالاختلاط ، وفسد الأسلوب واقتصر الناس على ما سطر في تعليم النحو والصرف ، ولا يخفى الصى أن مثل ذلك مثل من طلب الذكاء والفهم من مجرد

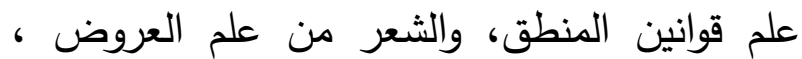
والأدب من كتب التربية ، متى لم يكن في فطرته

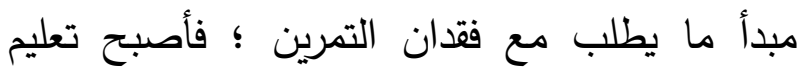

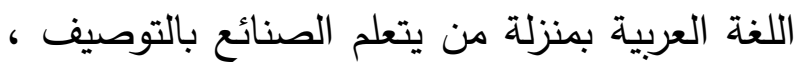

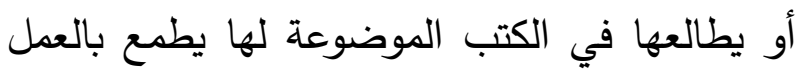

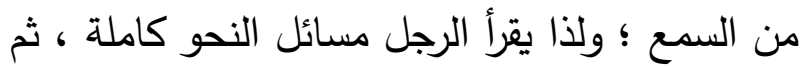
لا يكون من بعد قادرًا على تحرير رسالة أو قول

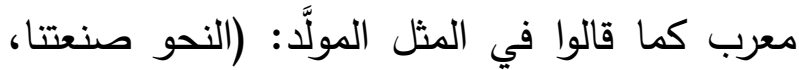

(1) ينظر محاضرة اتجاهات اللغة تعليم العربية في الأقسام الجامعية

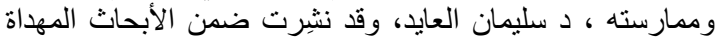

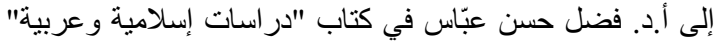
ص (r) ينظر القراءة الجهرية بين الواقع وما نتطلع إليه، ص : 10. 
المنزل على الرّسول منهم وبه هداياتهم، والإسلام

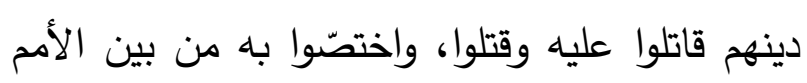

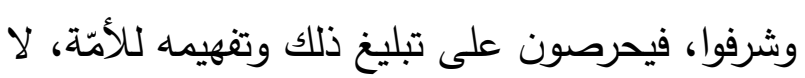

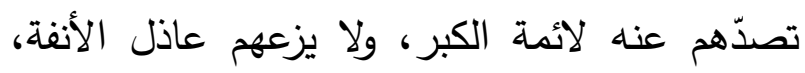

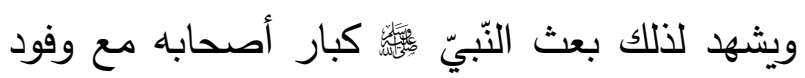
العرب يعلّمونهم حدود الإسلام وما جاء به من شرائع

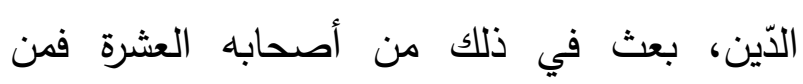

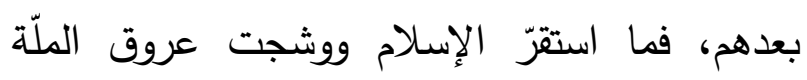

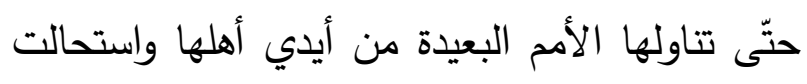
بمرور الأيّام أحوالها، وكثر استنباط الأحكام الثّرعيّة

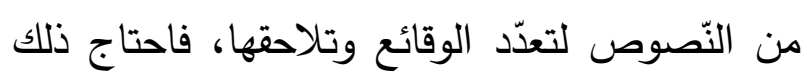
لقانون يحفظه من الخطأ، وصار العلم ملكة يحتاج

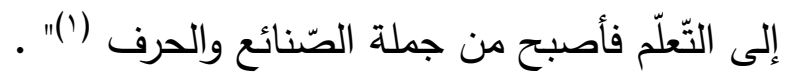

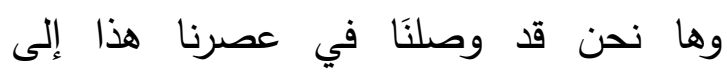
مجالات التخصص والصنعة والدّّقة ؛ حتى وجنَّا

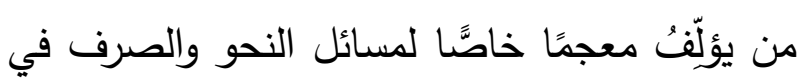
القرآن الكريم (؟). التدرج في التعليم من طرق التدربب :

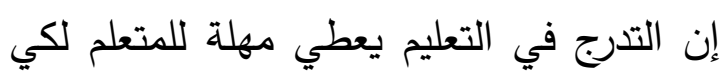

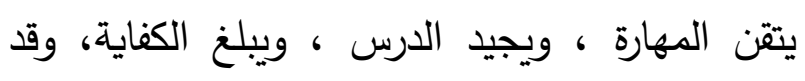

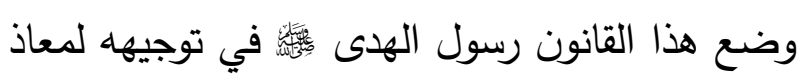

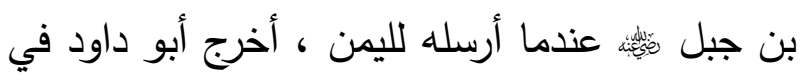

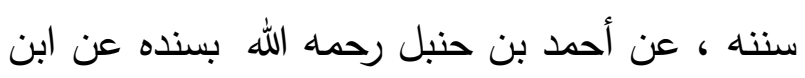

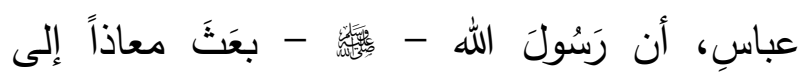

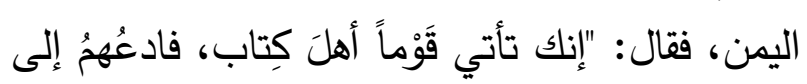

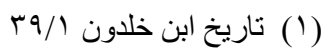

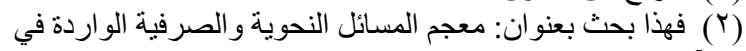
القرآن الكريم، الدكتور ف. عبد عبد الرحيم (فانيامبادي عبد الرحيم).
ولعلَّنا في هذا البحث المختصر نلفتُ أنظار الإخوة الفضلاء ممن نحسبهم حماة للعربية، وأهلاً

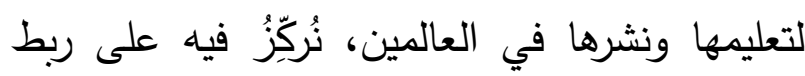

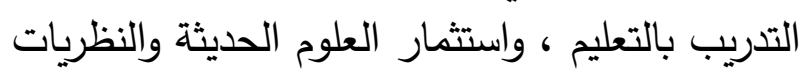

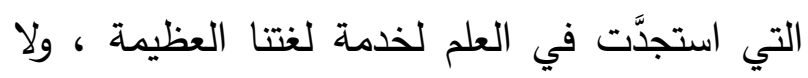

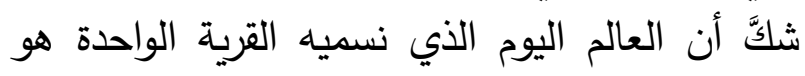
في أمسِّ الحاجة إلى الربط بين العيّ العلوم بنظرة جديدة

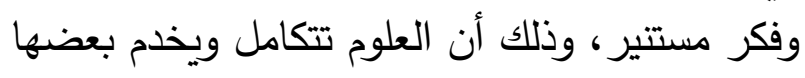

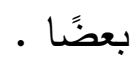

\section{التعليم بين الرسالة والصنعة:}

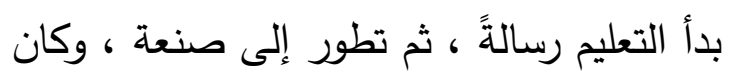

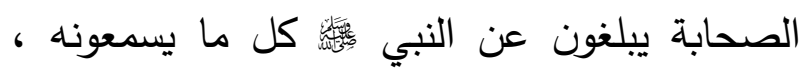

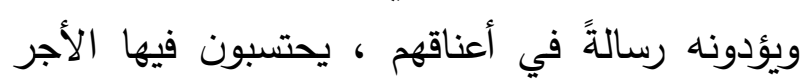

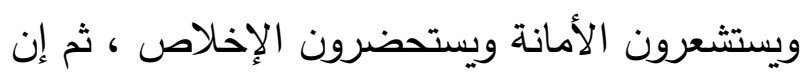

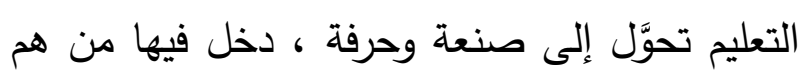

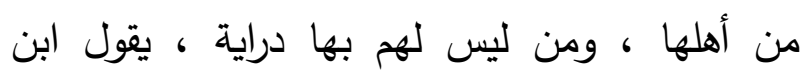

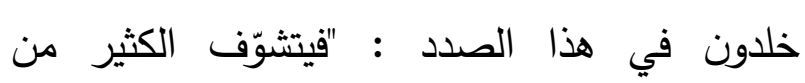
المستضعفين أهل الحرف والصّنائع المعاشيّة إلى نيل الصنيل

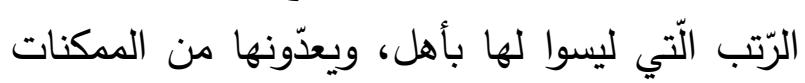

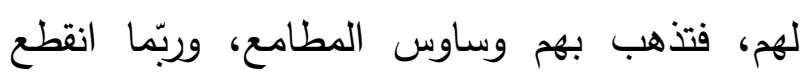

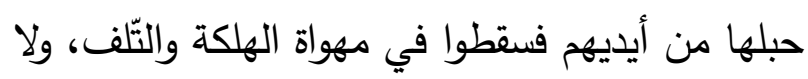

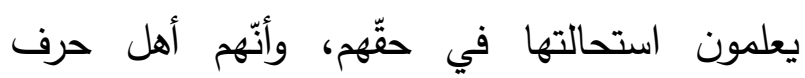

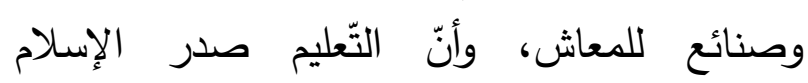
والدّولتين لم يكن كذلك، ولم يكن العلم بالجملة صناعة، إنّما كان نقلا لما سمع من الثّارع، وتعليما لما جهل من الدّين على جهة البلاغ، فكان أهل

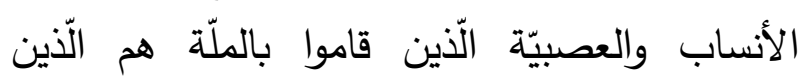

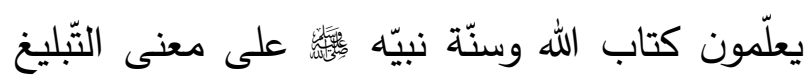
الخبريّ لا على وجه التّعليم الصّناعيّ؛ إذ هو كتابهم 
يُقصدُ بالتدريب المران على بعض الألغاز،

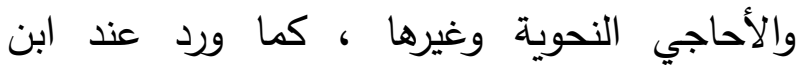
الثجري في أماليه ، ذكر الدكتور محمود الطناحي وغيرها

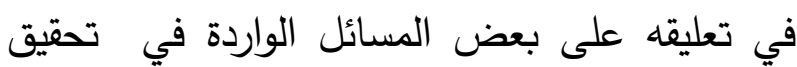
أمالي ابن الثجري قوله: "حكى هذه المسألة عن ابن الثجري: النّيوطي في الأشباه والنظائر (؛)، وأصلها عند المبرد في المقتضب(0). ومثل هذه المسألة يراد

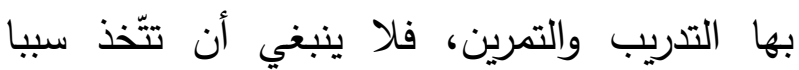
للطعن في النحو والنحاة، وقال: بعض مسائل النحو يراد بها التدريب والتمرين ليس غير (؟)". وذكره الجاحظ في البيان والتبيين تحت مسمَّى لهير

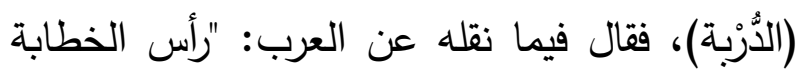

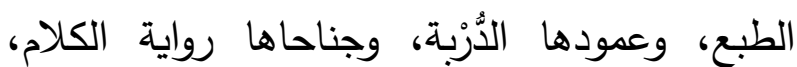

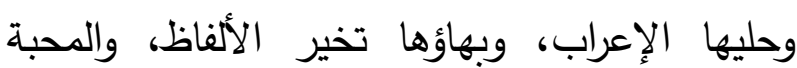

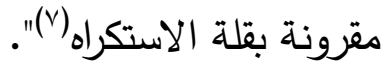

التدريب اصطلاحًا: "عملية سلوكية يُقصد بها

تغيير الفرد بهرف تتميته، ورفع كفايته الإنتاجية (^)"ا:، وهو علم انبثق من علوم الموارد البشرية إلَّا أنه

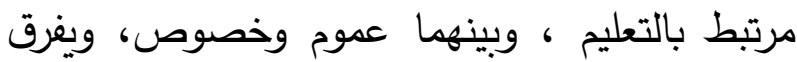
أهل هذا الفن بينه وبين التعليم من زوايا متعدِّدَة، وبنهات أُلِّْصُها في الجدول التالي:

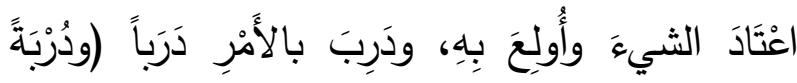

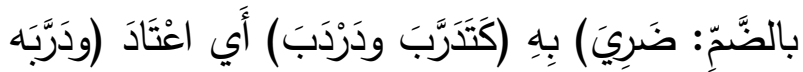

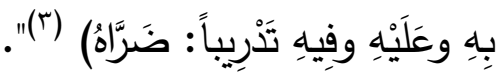
لم يُعرف مصطلح التدريب - قديمًا - بمعناه الاصطلاحي المعروف في عصرنا هذا، بل كان 


\begin{tabular}{|c|c|c|}
\hline التدريب & التعليم & الخصائص \\
\hline يركز على المعرفة و المهار ات & يركز على المعرفة النظرية & 1 ـ الهذف \\
\hline قصير الزمن & طويل الزمن & rـ الوقت \\
\hline المتدرب & المعلم & بــ المحور \\
\hline أساليب متعددة & التلقين أو المحاضرة & عـ الأسلوب \\
\hline
\end{tabular}

ودعائمه العلم، وبابه الدربة"، ثم نقل كلام القاضي الجرجاني عن أهمية الدربة وأنها مادة الشعرفقال: "قال القاضي علي بن عبد العزيز الجرجاني صاحب ولئ كتاب الوساطة: الشعر علم من علوم العرب يشترك بك

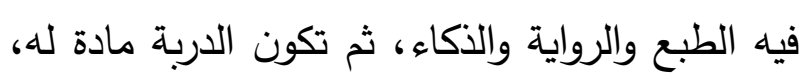
وقوة لكل واحد من أسبابه؛ فمن اجتمعت لله هذه الخصال فهو المحسن المبرز، وبقدر نصيبه منها تكون مرتبته من الإحسان (r)"ا. والعربية بعلومها المختلفة قائمة من أجل فئل

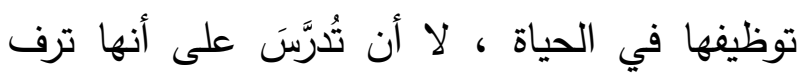
فكري، وأمثلة مصنوعة غير قابلة للتطبيق، ولهذا نجد ابن خلدون يُثني على أهل الأندلس في طريقتهم في تعليم العربية لارتباطها بالتطبيق، وعنايتهم فيها بالتدريب والتمرين؛ فيقول: "وأهل صناعة العربية في لإنياني الأندلس ومعلموها ، أقربُ إلى تحصيل هذه التمَكَكة

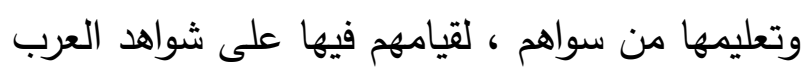
وأمثالهم، والتفقه في الكثير من التراكيب في مجالس تعليمهر، فيسبق إلى المبتدئ كثير من الملكَةِ أثناء التعليم ؛ فتقطع النفس لها ، وتستعد إلى تحصيلها وقبولها، وأمَّا من سواهم من أهل المغرب وإفريقية

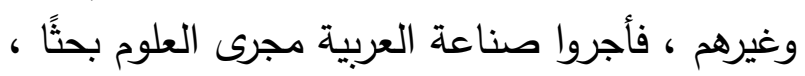

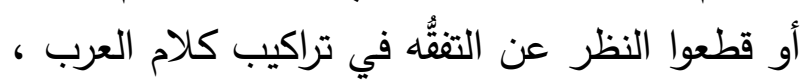

وتتعدد تعريفات التدريب وتتتوع ، إلَّا أن مضامينها تتشابه إلى حد كبير، وهي في مجملها تُركّزُ على أنه "جهد مُنظَّّ ومخطَّط لتطوير معارف وخبرات واتجاهات المتدربين ، وذلك يجعلهم أكثر فاعلية في أداء مهامهم"(') فيرات

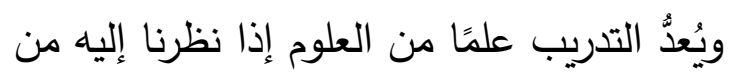

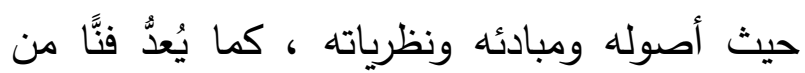
الفنون إذا نظرنًا إليه من حيث تطبيقاته .

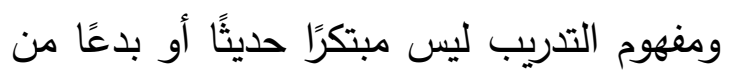

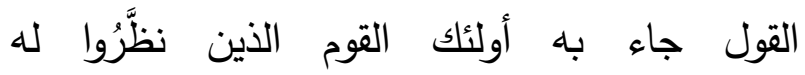
ولمصطلحاته ؛ بل هو أمر ممارس منذ القِدَم تدعو إليه الفطرة ، ويُحسِّنُه العقل في شتى مجالات الحياة، وكافَّةِ أنواع العلوم • وقد كان للسلفِ عناية بالتدريبات والتمارين في تعليم اللغة العربية ، يظهر ذلك جليَّا في ارتباط نشأة علم العربية بالسليقة والتطبيق ، وأنه جاء في الأصل

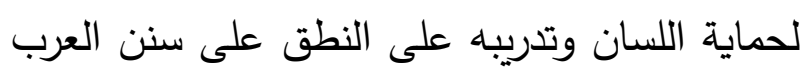
في كلامهم ، وقد سُمّي النحو كذلك دلالة على ونى انتحاء سمت العرب في كلامها . وتحدَّث ابن رشيق عن أهمية الدربة في بناء

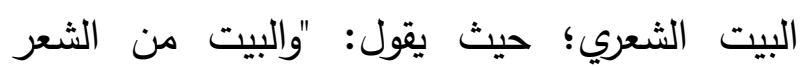
كالبيت من الأبنية: قراره الطبع، وسمكه الرواية، 
الصحيح حلًّل لهذا اللغز أو ذلك .

و "كان قدماء النحاة يُجرون كثيرًا من التحليلات النحوية في المجالس وحلقات التدريس، ويطلقون العبارات العلمية التي تبين الوظائف والصيغ ولين والمعاني الإعرابية، والعلاقات والتأثر والتأثير بين

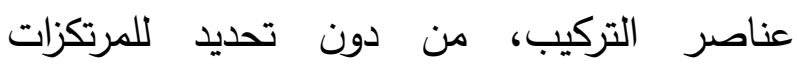
المنهجية التي يصدرون عنها، وليس ثمة من شك التركان

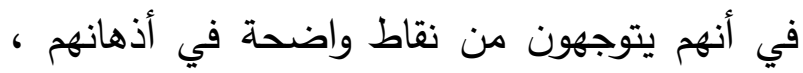

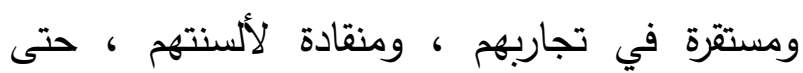

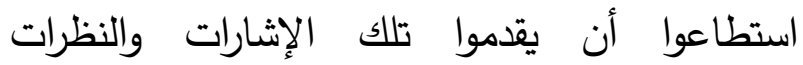

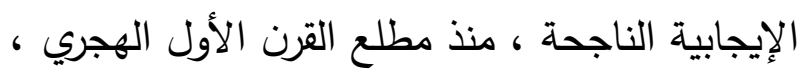

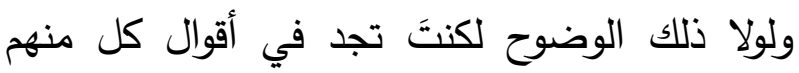

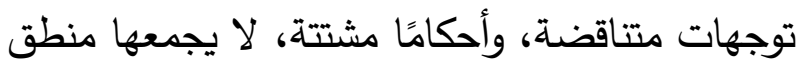
أو استقرار، فكيف وقد رأينا فيما صدر عن جمهور

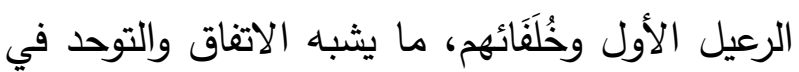

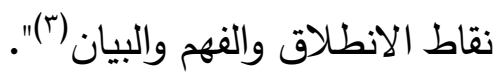
تُعدُّ الألغاز النحوية من أقلام المحاولات التهات التي

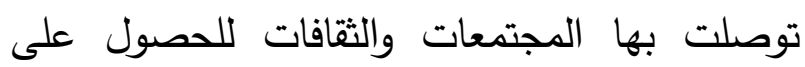

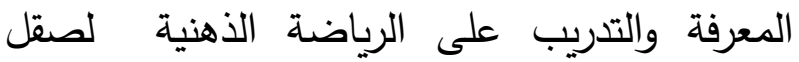

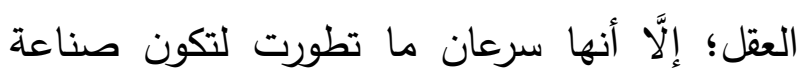

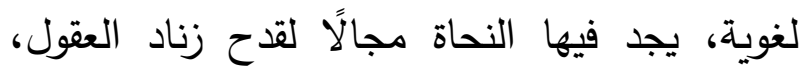

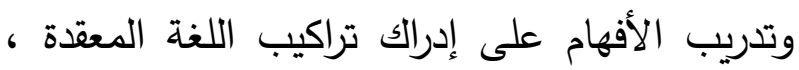
وكثفِ العلاقات بينها(؛)، ومن العلماء العاء الذين ألَّفوا

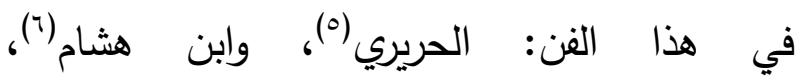

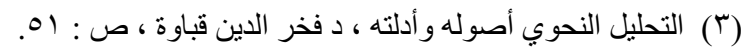

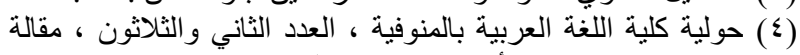

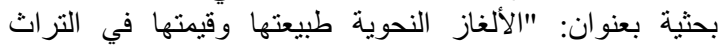

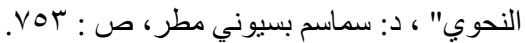

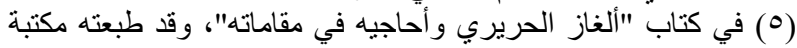

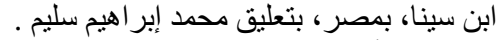
(7) في كتابه "الألغاز النحوية"، وقد طبعت إيعت دار الكتاب العربي طبعته

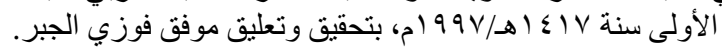

إلَّا إن أعربوا شاهدًا، أو رجَّحوا مذهبًا من جهة

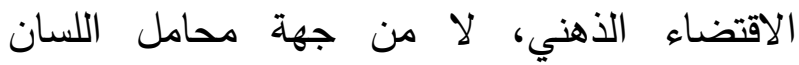

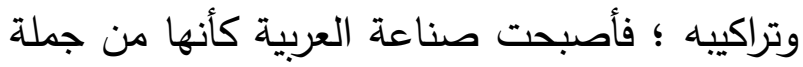

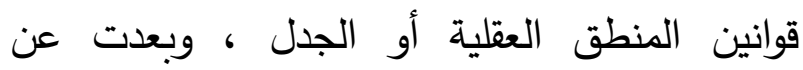

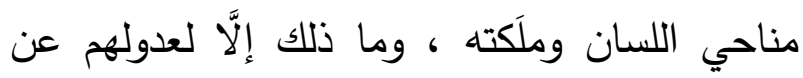

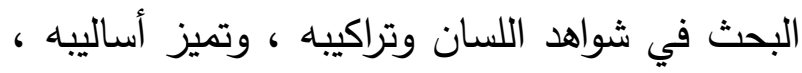

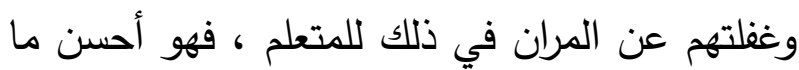
تفيده الملكة في اللسان (')". ومن المستحسن ذكره في هذا المقام ما نعرفه

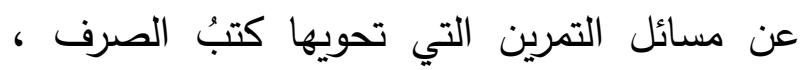
وهي مسائل تهدف إلى تدريب المتعلم على ضبط لتصن قوانين الصرف وتطبيقها بنفسه ليُعلم هل ارتبط في تلفي

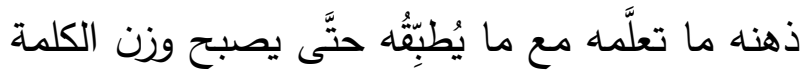
ومعرفة اشتقاقها ملكة عند الطالب، قد تدرب عليها من خلال أمثلة كثيرة ومسائل قد يستحيل استعمالها

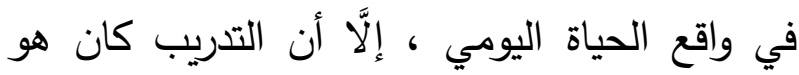

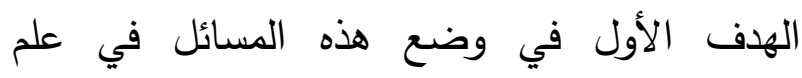
التصريف التصف "واللّغات إنّما هي ترجمان عما في الضمائر من

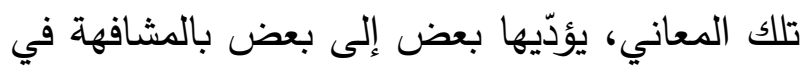

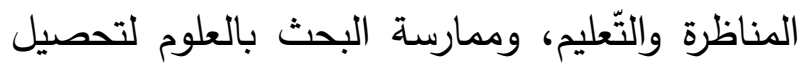
ملكتها بطول المران على ذلك (†)".

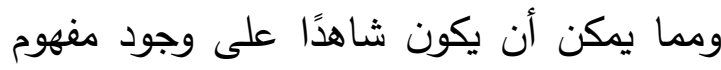

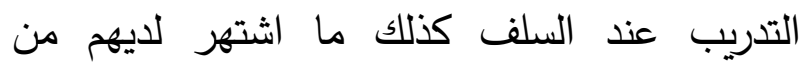

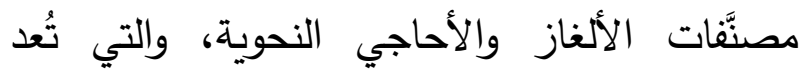
وسيلة تدريبية مؤثرة تشحن ذهن الطالب وتجعله يطيل التأمل والاستتباط لاستخراج الحكم النحوي توند 
المسألة بعد المسألة إلىى أن يبلغ الكسَائي إِلَى السّتر ،

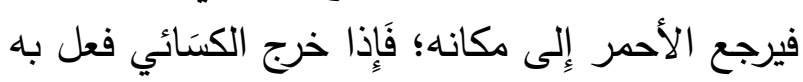
ذَّلِك، حَتَّى قوي وَتمكن (أَ)".

ومن الوسائل التدريبية التي سبق السلف إليها ما نقلته كتب النحو واللغة من محاورات ومناظرات

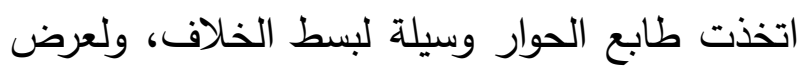

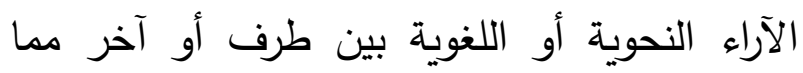
جعل تلك المحاسن يتسابق إليها الطلاب استمتاءعًا

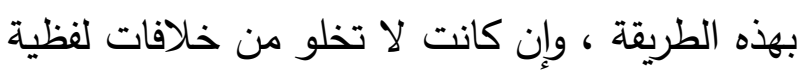
أو فلسفة منطقية أو عصبية مقيتة، ومع هذا كله كله فإنها تُعد "من أهم الوسائل لدراسة هذا العلم بقسميه:

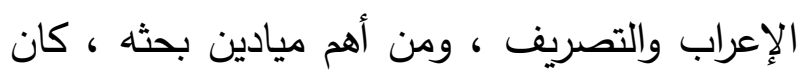

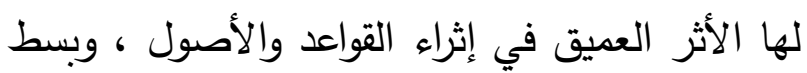
المسائل وتحليل القضايا(ث)". ولقد كان من أهم آثار مجالس المناظرات الإقبال المتحمس لطلب العلم، والجد في تحصيل مسائله، والتفوق على الأقران، وبالنظر إليها كظاهرة

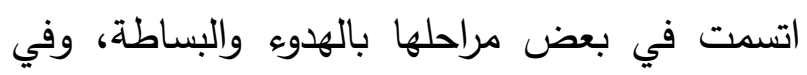

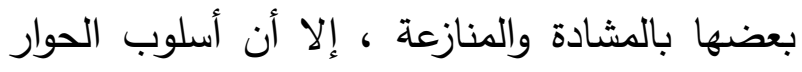

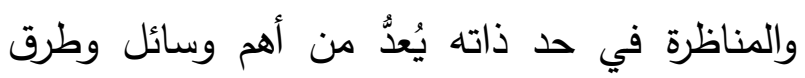

التدريب التي يمكن استخدامها في تعليم العربية . وقد ذكر السيوطي في كتابه الألغاز النحوية

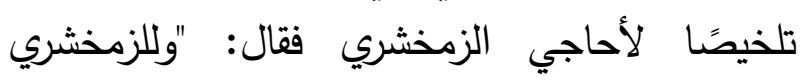

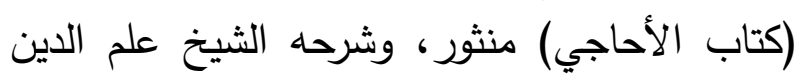
السخاوي بشرح سماه (تتوير الدياجي في تفسير الأحاجي) وأتبعه بأحاجي له منظومة، وأنا ألخص فيل لتصيل

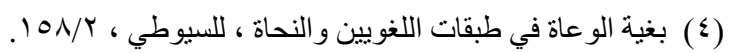

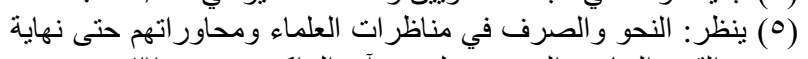

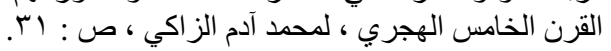

والسيوطي(')، والأزهري(؟)، وقد اختلفت أشكال

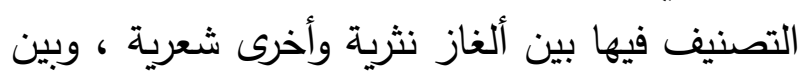
ألغاز مصنوعة ، وأخرى مروية ، وهي في مجملها لفياز

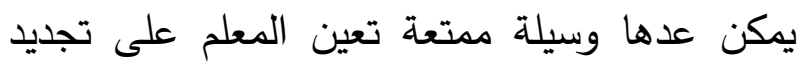

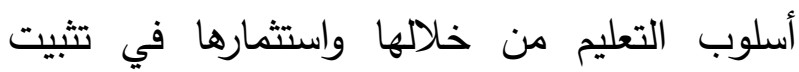

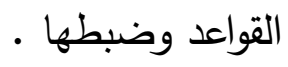

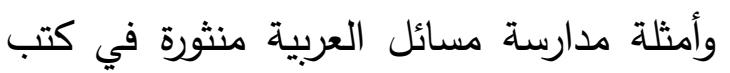
التراث بكثرة ووفرة، ومن أمثلة ذلك ما ذكره السيوطي رحمه الله عند ترجمة شيخه الكافيجي رحمه الله فقال:

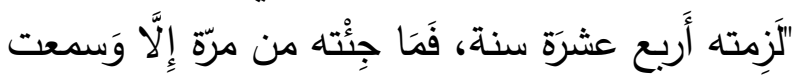

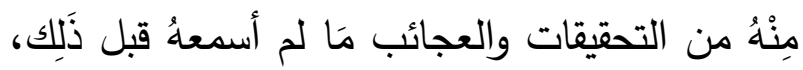

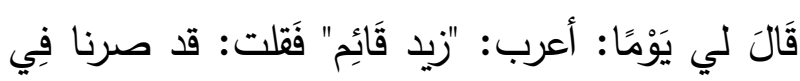

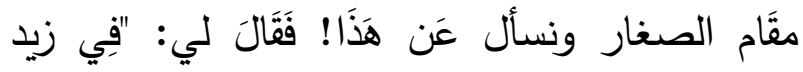

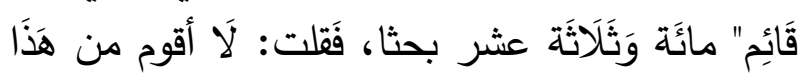

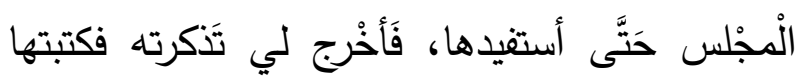

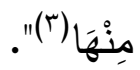

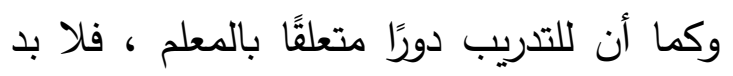
من دور للطالب في ذلك أيضًا ؛ ألا وهو الحب دأبطا

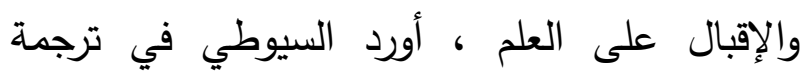
(الأحمر شيخ العربية) وكان تلميذًا للكسائي: "كَانَ

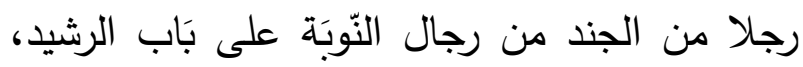

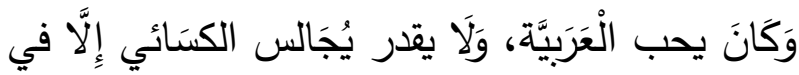

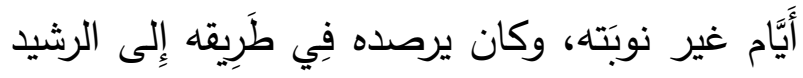

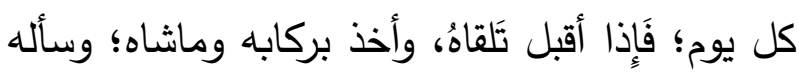

(1) في كتابه "الطراز في الألغاز"، وطبعته الدكتبة الأزهرية للتراث

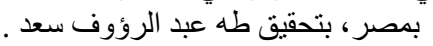

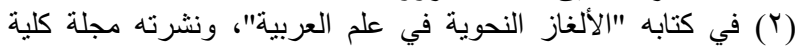

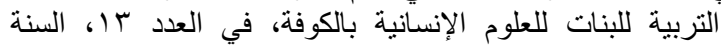

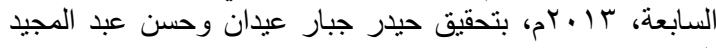
الشاعر.

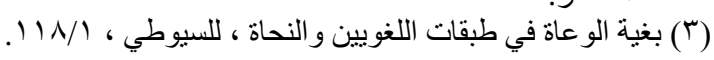




$$
\text { الفن وتفاريعه، وحسن تصرفه فيه (ז)". }
$$

وذلك "لأن صناعة العربية إنما هي معرفة

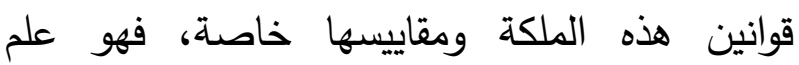
بالكيفية، لا نفس كيفية؛ فليست نفس الملكة، وإنما

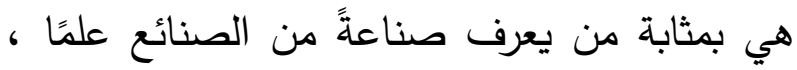

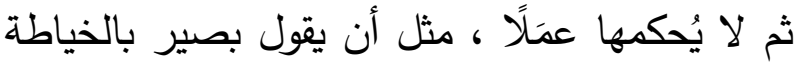
غير محكم لملكتها في التعبير عن بعض أنواعها:

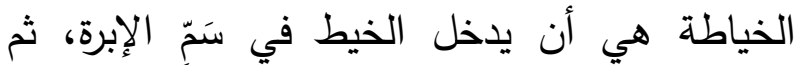
يغرزها في قطعتين من القماش مجتمعتين، ثم هو لو طولب بهذا العمل أو بشيء منه لم يُحكمها، وهكذا

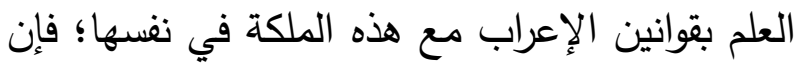

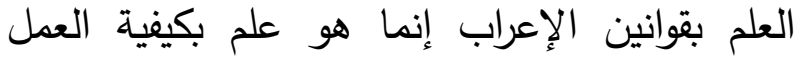

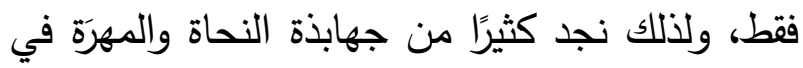
صناعة العربية المحيطين علمًا بتلك القوانين إذا

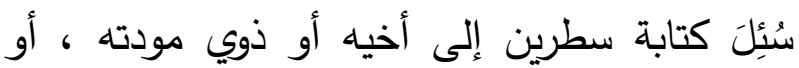

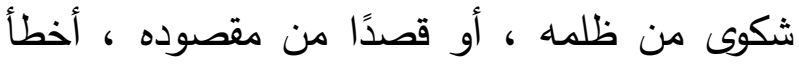

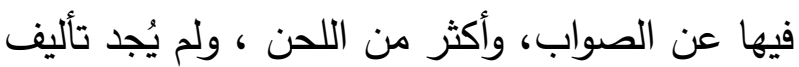
الكلام لذلك ، والعبارة عن المقصود على أساليب اللسان العربي ، وكذا يوجد كثيرٌ ممن يحسن هذه العند

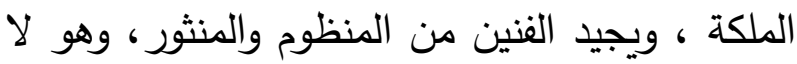

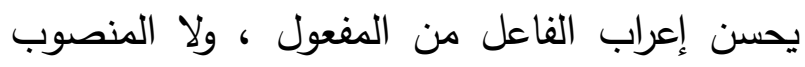

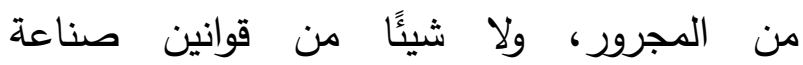
ثم إنه وصف هؤلاء بأنهم ممن حصل على على علم ولم

اللسان صناعة، ولم يحصل عليه ملكة (؛). "إن تعلم اللغة تدريب يختلف عن أكثر الموضوعات المدرسية الأخرى؛ فهو ليس قضية اكتساب معلومات معينة، ولا مسألة استيعاب حقائق
هذه نُتنق بسيطة من جذور مفهوم التدريب وتطبيقاتها في تاريخ العربية ومسالك لعنية علمائها

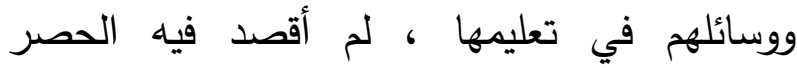
والاستقصاء ، وإنما هدفنا التتبيه والتذليل على أهمية هذا الفنّ، ووجوده في تاريخنا المضيء ، ويكفي من هن

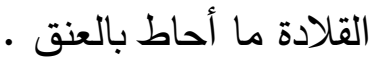
التدريب والمهارات اللغوية: إن تعليم اللغة العربية والتدريب عليها يجب ألَّا يقتصر على دراسة القواعد والمصطلحات الصرفية والنحوية فحسب؛ بل يجب أن يتعدى هذا كله إلى

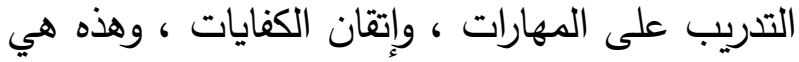
الثمرة الحقيقية لتعلم اللغة العربية . وقد سبق أن أشرنا إلى أن من يعرف التدريب

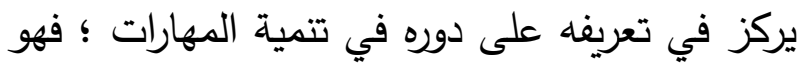
لا يكتفي بإكساب المتدرب المعرفة ؛ بل يتجاوز هذه في دئه

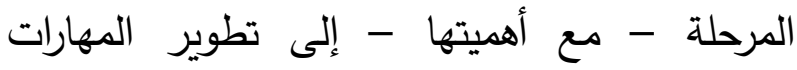
وتتميتها ، وهذا فارق كبير بين التدريب والتعليم

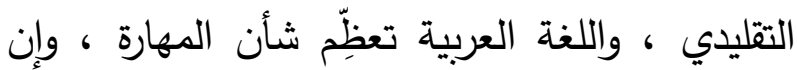
كانت تستخدم الصناعة مرحلة أولى في التعلم إلَّا

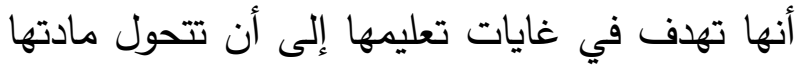

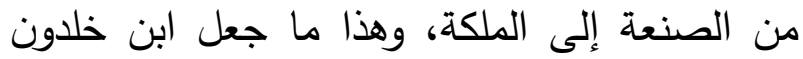
يفضل مصنَّفات ابن هشام على غيرها من الكتب الكناه التي اقتصرت على التظير والحواشي؛ حيث هيثام يقول عن ابن هشام إنَّه: "استولى على غاية من ملَكَة تلك

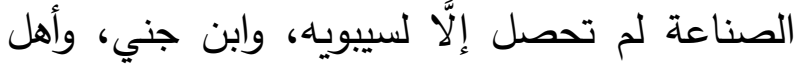
طبقتهما؛ لعظم ملكته، وما أحاط به من أصول ذلك ولك ولك

(1) الألغاز النحوية (الطراز في الألغاز) لجلال الدين السيوطي ، /T/ . 
فن الإلقاء، هي: الموهبة، الاستعداد الشخصي،

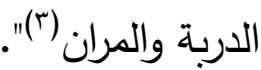

بل إن المجتهد في الدربة والمران قد يفوق صاحب الموهبة المعرض عنها، "ولكي ندرك أهمية التدريب والممارسة علينا أن نقارن بين إنسان حصلت عنده ملكة أو موهبة قوية ولا يدرب نفسهاه،

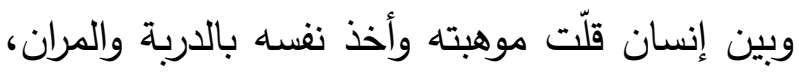
فسنجد الذي قد تدرب فاق صاحب الموهبة(؛). وحتى في العلوم المتعلقة بالعربية وخدمة فنونها نحتاج إلى الدربة والمران: "وجمال الصوت هبة من الصنات

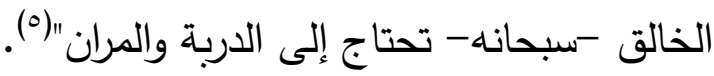
وتحتاج الكتابة إلى الدربة والمران: "إن أي لون الكان

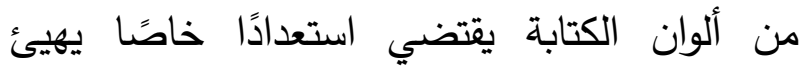
صاحبه للقيام بهذا العمل، ومما لا يتطرق إليه الثك الثك الثكان

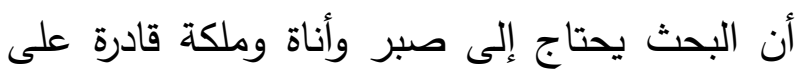

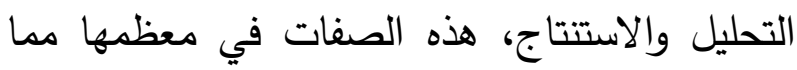
يحتاج إلى الدربة والمران، ورياضة النفس وحملها على المشقة والمعاناة، فضلًا عن القدرات الذهنية

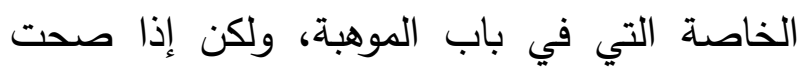
العزيمة وقويت الإرادة فيمكن -بمعونة الله سبحانه وتعالى - أن تنمى الاستعدادات الفطرية البسيطة

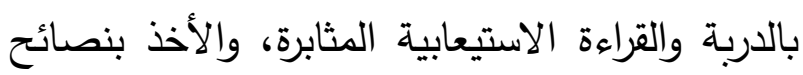
الباحثين الكبار، والاستفادة من تجاربهم، وتَرَسُّم

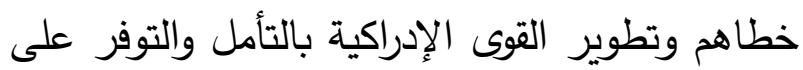
المسائل والتعمق فيها. (1)"." ولقد ظفرتُ بكتاب نفيس لعالم جليل عرف عنه
بعينها، ولا هو بناء معرفة في المواقف الأكاديمية أو العمليات الفكرية، ولكنه يتجاوز ذلك كله إلى تكوين المهارات والعادات اللغوية (')". إن إتقان أداء المتعلم وقياسه يتعلق بقدرته على تطبيقه لمهارات اللغة الرئيسة والفرعية؛ فالرئيسة الفئه

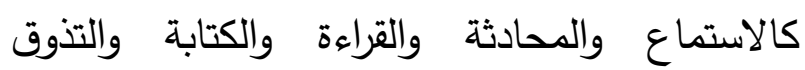

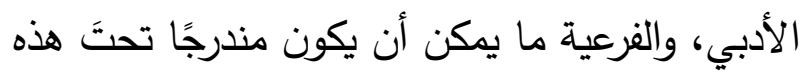
المهارات؛ ولهذا فقد انتُّدت المدرسة التعليمية القائمة

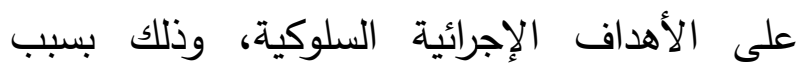
نظرتها التجزيئية للسلوك الانعكاسي في مقابل ما لإني ينادي به التربويون من إبراز لدور النظرة التكاملية بين المهارات والثمولية في تتاولها (r).

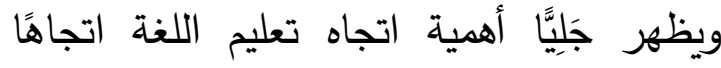
وظيفيًا ، يركز فيه المعلم على بناء القدرة الذاتية

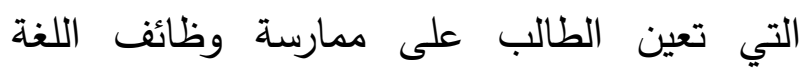
الأربعة ممارسة صحيحة في حياته ؛ مما يؤدي بعد

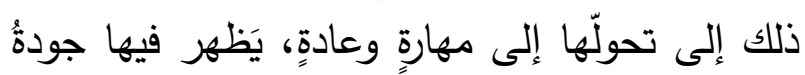

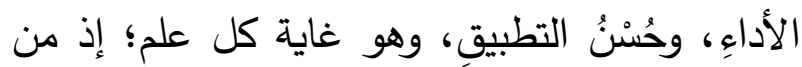

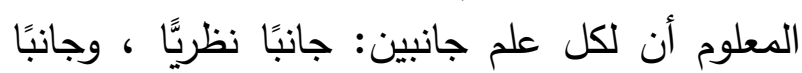

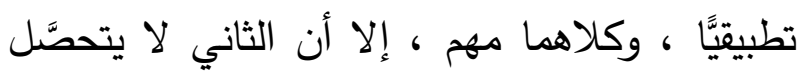

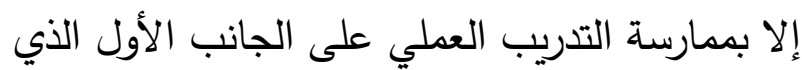

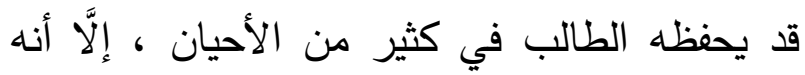
يفتقد للمران والممارسة التي توفرها له أساليب التعليم التي تعتني بالمهارات اللغوية . وتُشترطُ الدربة والمران لإكمال مهارات الملكة

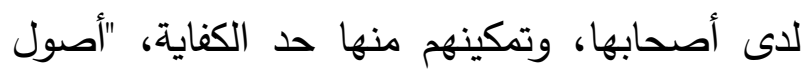

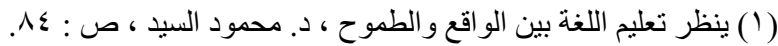

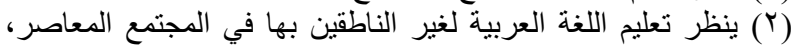

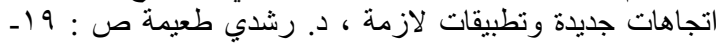


جودة التحقيق ودقة التفكير، وهو الطاهر بن ومكارم الأخلاق (')". ولقد تتاولت رائدة من رائدات الشعر الحر أهمية

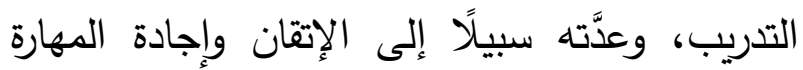
عاشور، صاحب تغسير "التحرير والتنوير"، وكتابه

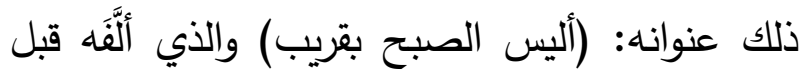
وصقل الموهبة: "وذلك لأن ما تقبله إذن شائه شاعرة

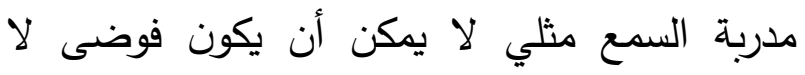

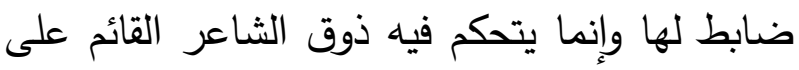
التدريب السمعي البطيء عبر سنين طويلة من قراءة

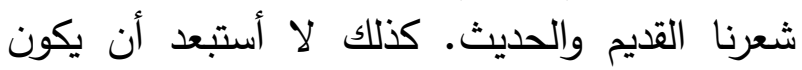
سمعي العروض متأثرًا بالوزن الإنكليزي والفرنسي لتهي لكثرة ما أقرأ من شعر بهاتين اللغتين. ولا يعني هذا

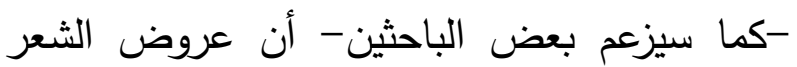

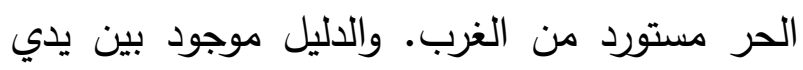

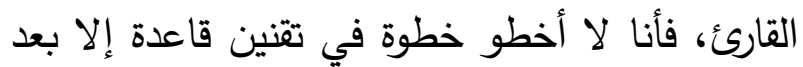
استثارة "عروض الخليل" التي خبرة فئ مداخله

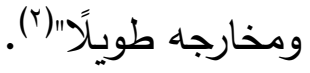

ويرى بعض المهتمين بالتراث العربي "أن الإضافة الحقيقية التي ينبغي تقديمها لهذا التراث: هي إعادة قراءته وتقديمه على النحو المناسب للسياق العلمي الراهن؛ إذ تمثل النظريات اللغوية المعاصرة تحدِيًا غير بسيط لتراثنا اللغوي يستلزم أن نراجعه إنهاه

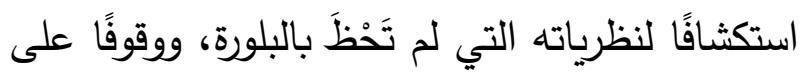
طرقه المختلفة في معالجة المشكلات اللغوية التي تعالجها النظريات اللغوية الغربية المعاصرة"(َ).

$$
\text { مفاهيم التدربب : }
$$

يمكن وصف عملية التدريب واختصارها في الرسم التالّي: - (التي

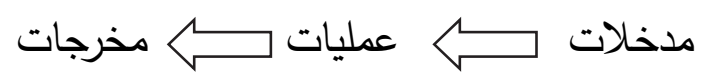

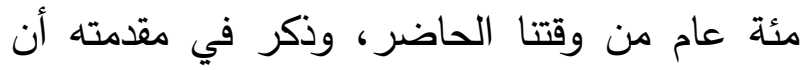
موضوعه وسبب تأليفه هو التفكير في طرق وني إصلام فيلاح

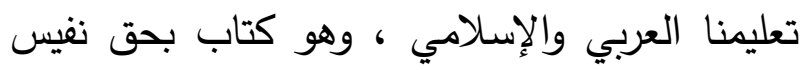

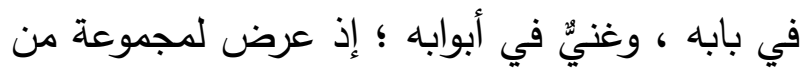

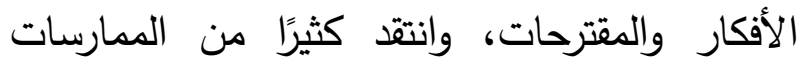

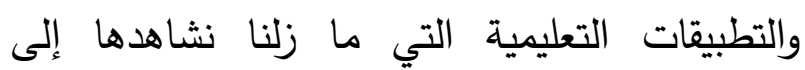

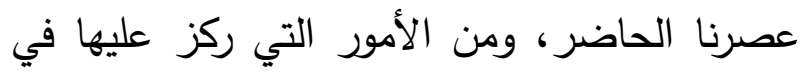

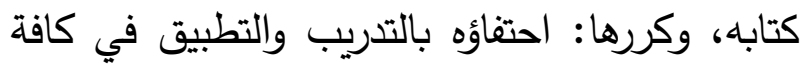

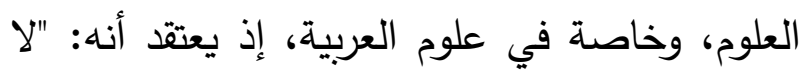

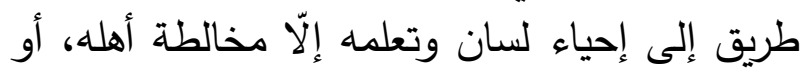

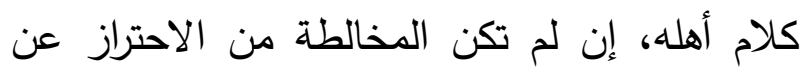

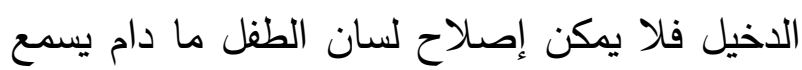

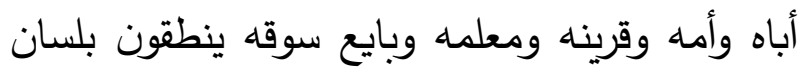

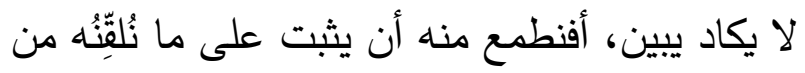

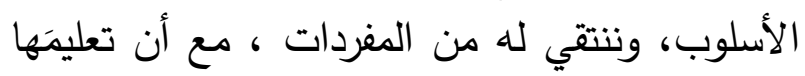

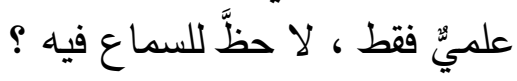

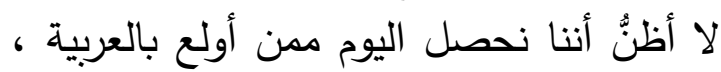

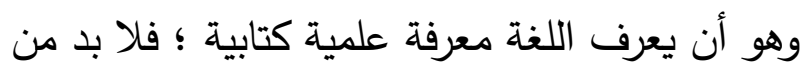

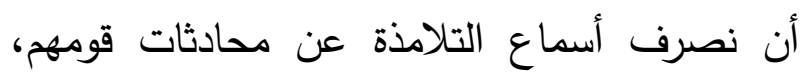

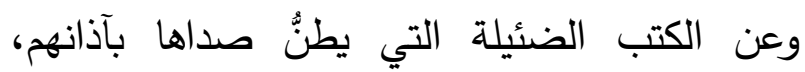
بإنشاء مدرسة خاصة لتعليم اللغة، يدخلها التلامذة لطنة من صغر السن؛ فيؤدبون على النطق باءئ بالعربية الفصحى بوجه عملي تمريني، بمساعدة أساتذة ذوي

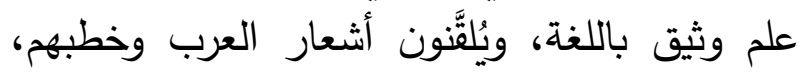

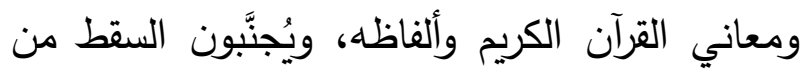
شعر المولدين من جهة الألفاظ ، أو من جهة الآداب 
قياس الأداء وتقويمه، ومدى تأثره بالعمليات التي مر

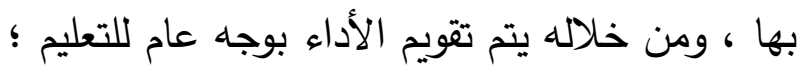

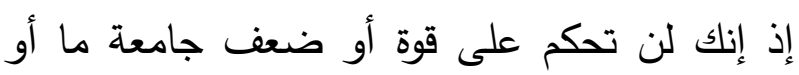

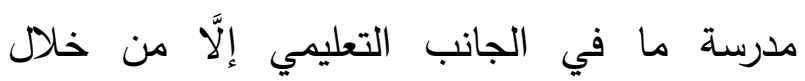

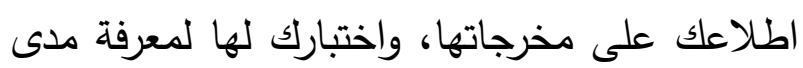
الإتقان الذي وصلَتْ إليه، وللتندريب مفاهيم كثيرة

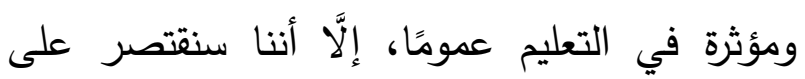

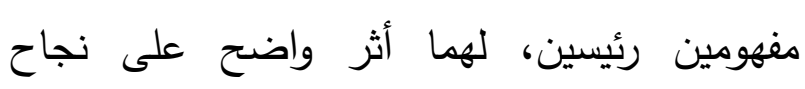
التدريب، وهما ركنان من أركان العملية التدريبية،

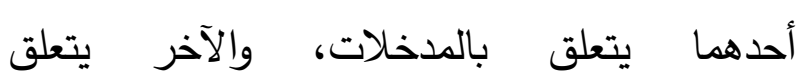

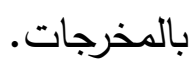

\section{مفهوم تحديد الاحتياجات التدريبية:}

وهذا الدفهوم هو العملية الهامة التي تضمن التئن الجدوى المنشودة للتدريب ، وكذلك تُعدُ الخطوة الأولى والأساسية التي ينبني عليها ما يلحقها من

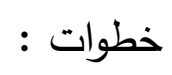

تحديد الاحتياجات التتريبية ريط تخطيط

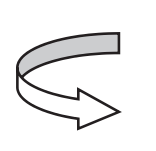

$$
\text { وتصميم البرنامج التنريبي }
$$

تقويم التدريب > طب تنفيذ البرنامج التدريبي

وهو الذي يبين الفئة المستهدفة ومواصفاتها ويساعد المسؤولين عن البرامج التدريبية وتتفيذها على التخطيط الجيد القائم على معرفة أنماط الهتعلمين أو المتدربين واحتياجاتهم، كما أنه يعد الندان
وهذه العناصر الرئيسة الثلاثة لأي عملية تدريبية، إذ يقتضي التدريب معرفة الدذخلات التي لتئية نعبر عنها في التعليم بالطالب، وما يتبع هذه المعرفة من مفاهيم نظرية وأساليب عملية يمكن أن تندرج

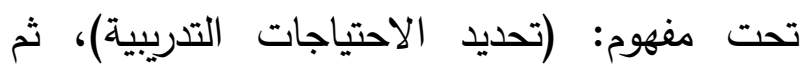
تجري على هذه الدذخلات مجموعة من العمليات المخطط لها، والتي تراعي هذه الفئة الدستهدفة، وهو ما يمكن أن نسميَه في التعليم: (مناهج وأساليب

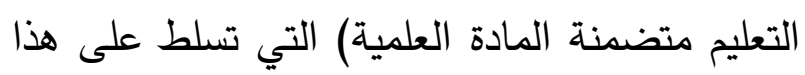
الطالب أثناء دراسته، وهذه العمليات يراعى فيها

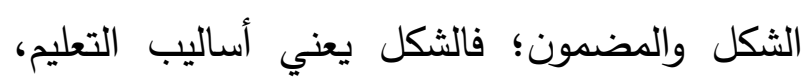
والمضمون يقابله مادة العلم المراد إيصاله، وهذا العنصر يمكن أن يقابله في التتريب أساليب وطرق التياله التدريب ، وهو ما سنعرض له في في المبحث القادم، لقابل وأمًا العنصر الثالث: فهو الدخرجات، وهي لبُ لبن العملية التعليمية وغايتها ، وحولها ندندن ، ومن التهن

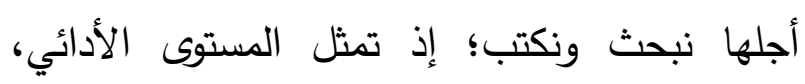
والنتيجة العملية لتلك العمليات التي مرت بها لتها هذه

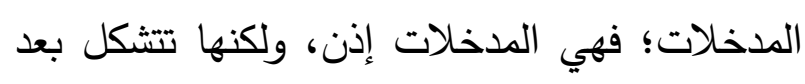

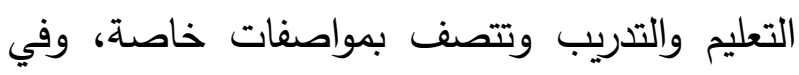
هذه المرحلة يظهر أثر العملية التعليمية أو التدريبية

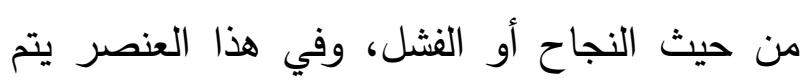


ذلك مما يتعلق بدقائق المسائل النحوية، واختلافات العلماء، ولا شكَّ أن اختلاف هذين المقامين والغايتين يستوجبُ اختلافًا في طريقة التعليم ، واختيار المناهج التعليمية ، كما أن في هذا المفهوم تحديدًا لمتطلبات التغير المطلوب تبعًا لمواصفات المخرج الذي نسعى إليها .

وتحت هذا المفهوم تبرز أهمية قصوى لتحديد أنماط الشخصية لدى المتعلمين، وهذا باب شائق شائك، وهو من الأهمية بمكان، إذ يتفق الناس كلهم على شيء واحد، وهو أنهم مختلفون، ومعرفة اختلافاتهم فيما بينهم يؤدي إلى اختيار الأساليب المناسبة لكل نمط ؛ فليس كل الطلاب تؤثر عليهم وسيلة واحدة من وسائل التدريب أو التعليم ، ومن لهن هنا نشأتُ أنماط التعليم ومفاهيمه ، وهني وهي منصبَّة على تحليل أنماط الشخصيات، والتشخيص الصحيح يوصل إلى التدريب والتوظيف الصحيح .

ولقد التقت إلى هذه القضية سلفُنا الصالح ، وعُنُوا بأهمية موافقة شخصية المتعلم لطرق التعليم؛ حيث يقول ابن بدران: "حاصلُ الأرر أن الأستاذ ينبغي أن يكون حكيمًا يتصرف في طرق التعليم بحسب ما يراه موافقًا لاستعداد المتعلم، وإلّا ضاع

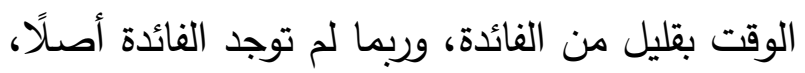
وطرق التعلم أمر ذوقيُّ، وأمانة مودعة عند الأساتذة، وندا، فمن أداها أثيب على أدائها ، ومن جحدها مودها كان

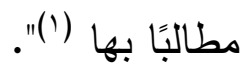

وأذكرُ هنا نموذجًا واحدًا من نظريَّات التعلم
المؤشر الذي يوجه التدريب في طريقه الصحيح، والمعيار الذي يُحتكم إليه بعد العملية التدريبية. ويُقصد بتحديد الاحتياجات التدريبية: المؤشرات التي تكثف الفرق بين الأداء الحالي، والأداء المرغوب فيه، ويمكن توضيحه بالرسم التالي: واقع الطالب اللغوي التدريبي صـه الأداء المتوقع من الطالب فالاحتياج التدربي: هو مرحلة الكثف عن نوعية هذه المدخلات، التي يُسعى فيها إلى إجراء عمليات تدريبية، وتعليمية عليها ، وذلك لتحقيق أهدافٍ منها: 1-تحديد أنماط التعليم أو أساليب التدريب المناسبة لأنماط الشخصيات وسماتهم . r- تحديد المؤشرات التي سيبنى عليها القياس والتقويم لهذا المدخل فيما بعد . ب- تحديد أهداف التدريب بدقة ووضوح • ع- الوقوف على دوافع ورغبات المتعلمين أو المتدربين لتوظيف التدريب لخدمة هذه الدوافع والاحتياجات . وهذا المفهوم يحدد متطلبات الوظيفة من معارف ومهارات واتجاهات، ونقصد بالوظيفة هنا في تعليم العربية: المكان الذي يجب أن يصل إليه هذا الطالب، مراعاة لحالته وحاجته؛ فقد يُطلب من جهة تعليمية أن تخرج باحثين متخصِصين في اللغة العربية، وأخرى يُطلبُ منها أن تخرج طلبة يطبقون مهارات اللغة الأساسية، ولا يطلب منهم أكثر من 
- يعرّف كولب أساليب التعلم على أنه مفهوم اجتماعي نفسي في المقام الأوّل ولا تحدّده السمات الشخصية إلا بصورة جزئية، وهو يتأثر

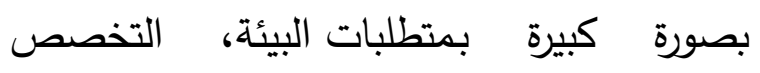
التعليمي، المهنة، العمل، مهارات الأداء. - كونه يعتبر أساليب التعلم تفاعلا بين عوامل وراثية وأخرى بيئية وبالتالي فهو لا يغفل أيا منها. - تأكيده على قابلية أساليب التعلم للتغيّر النسبي وثباتها النسبي أيضًا(ب).

ويستند نموذج (ديفيد كولب) على محورين (أفقي، ورأسي)، الأول: الفعل، والثاني: المعرفة، ويمكن رسم النموذج على النحو التالي، حتى يسهل ولئي علينا استيعابه:

(ץ) مقالة: أساليب التعلّم مفهومها و أبعادها و العو امل المشكلة لها حسب https://revues.univ-. نموذج كولب للتعلم الخبراتي، أ/ ربيعة جعفور ouargla.dz/index.php/numero-11-ssh/1477-2013-06-10-
المبنية على استثمار معرفتنا بأنماط الثخصيات في ، اختيار الوسائل والطرق المناسبة للتعليم والتدريب لمبن وأحسب أن فيها فائدة كبيرة لاكتشاف هذه الأنماط عند تحليل الاحتياجات التدربيية للطلاب الذين نسعى لتدريبهم وتعليمهم العربية بكفاءة عالية، ذلك الك أن العناصر الثلاثة لتحديد الاحتياجات التدربيية: (تحليل الفرد، وتحليل المنظمة، وتحليل الوظيفة)، والعنصر الأول هو ما يهمنا هنا ('). وهذا النموذج الذي اخترته، هو نموذج (كولب التعليمي (r) والذي لقي اهتماما متزايدا من الباحثين في الغرب على مدى العقدين الماضيين في البحوث والدراسات النفسية، وذلك لأن علماء النفس يرون أن نموذج التعلم الخبراتي معد بصورة جيدة وهو جدير بالاهتمام والتطبيق في المجال التربوي والباحث يميل لتبني نموذج كولب لأساليب التعلم نظرا للاعتبارات التالية:

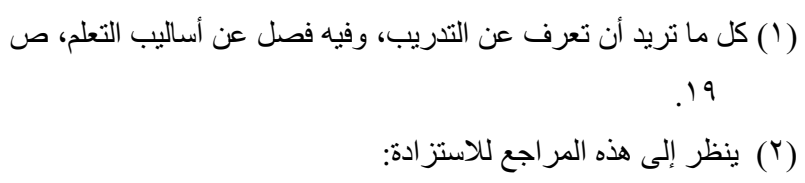

Alice Y . Kolb \& David A. Kolb(2005): The Kolb Learning Style Inventory- Version 3.1Technical Specification.Case Western Reserve University May 15.2005

Kristen C.Schellhas(2006):Kolb's Experiential Learning Theory in Athletic Training Education:A Literature Review. Athletic training education journal 2(apr- dec):18-27.

Ponle Gideon Adetunji: AN EVALUATION OF DAVID KOLB'S THEORY OF LEARNING STYLES.the Nigerian Baptist theological seminary'ogbomoso،oyostate.Ilorin Journal of Education. 

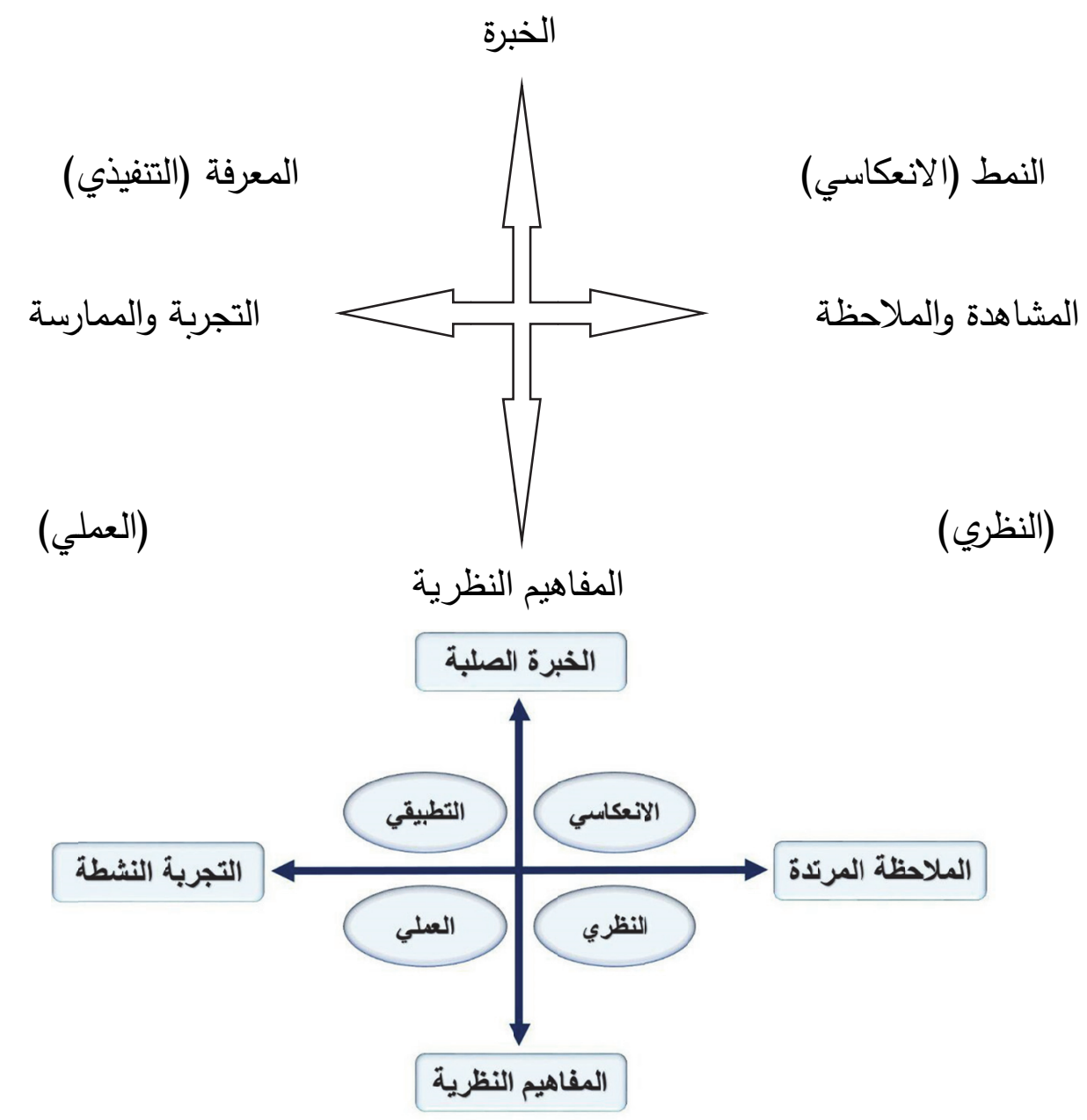

\section{نموذج كولب لأنماط التعلم والمتعلمين}

ولشرح المصطلحات الموجودة في الرسم نختصرها فيما يلي : الخرح

1- الخبرة: ويُقصد بها لها أن المتعلم في هذا الاتجاه يعتمد في إدراكه للمعلومات على الواقع

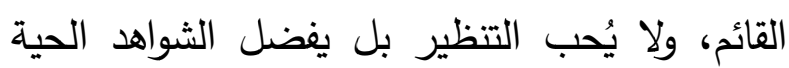
والأمثلة العلمية في تعليمه .
ويمكن شرح الرسم السابق على النحو التالي:

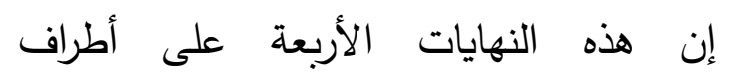

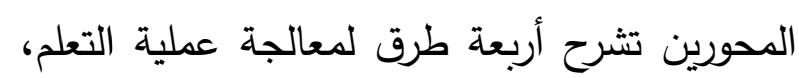

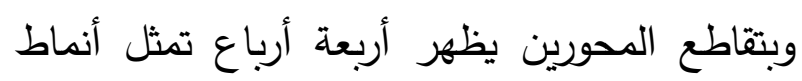
المتعلمين، ولكل نمط من هذه الأنماط ما يناسبها من وسائل وأساليب التدريب أو التعليم. 
المشكلات لأنهم يحبون أن يلمسوا أو يروا كل شيء • بأنفسهر ومن خلال هذه الاتجاهات الأربعة في نموذج (كولب) تتولد أنماط التعلم الأربعة: 1- الانعكاسي : (خبرة + ملاحظة) .

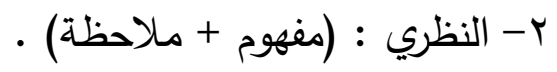
r- العملي : (مفهوم + فعل)، وهذا النمط : النط يقدم المفهوم على الممارسة . أمعام ع- التنفيذي: (خبرة + فعل)، وهذا النمط يقدم

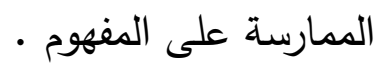
ويمكن تحديد الأساليب التدريبية لكل الأنماط السابقة للتعلم في الجدول التالي : r- الملاحظة: ويُقصد بها أن المتعلم يعتمد في تعليمه على المشاهدة والملاحظة الخارجية قبل إعطاء الحكم، وهؤلاء أكثر انطوائية، ويحبون أن أن يكون أداؤهم مُقاسًا بمعايير خارجية .

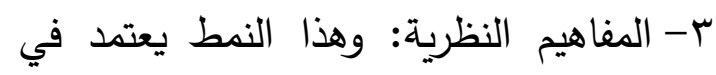
استقباله للمعلومة على التحليل والتفكير المنطقي، ولفئ والتقييم العقلي، ويحب أسلوب التعلم بالاكتشاف ولتفيل

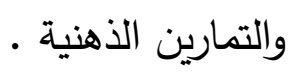

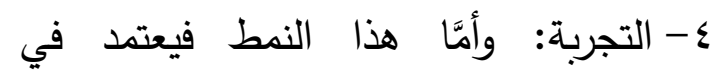
استجابته للتعليم على التجربة المباشرة، والممارسة

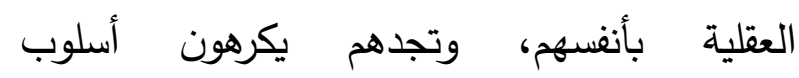
المحاضرات في التعليم، ويميلون إلى أساليب مختلفة، كأسلوب مجموعات النقاش أو حل حل

\begin{tabular}{|c|c|}
\hline الأساليب التدريبية المناسبة لهذا النمط & 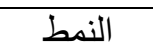 \\
\hline قعلصنة - تجارب - أمثلة - أقو ال مأثورة - مجموعة نقاش - عروض & الانعكاسي \\
\hline ذهنية . محرة - دراسات وأبحاث - أفلام وثائقية - حالة در اسية - تمارين & النظري \\
\hline تدريب وتطبيقات عملية ـ تمثيل أدوار - ورش عمل - بحوث ميدانية. & 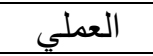 \\
\hline التعلم بالاكتشاف ــ ألعاب ـ التعلم التعاوني. & التنفيذي \\
\hline
\end{tabular}

وهناك نماذج ونظريات أُخرى يمكن استثمارها وأثرها في العملية التعليمية ، ولا يقل أهمية عنها

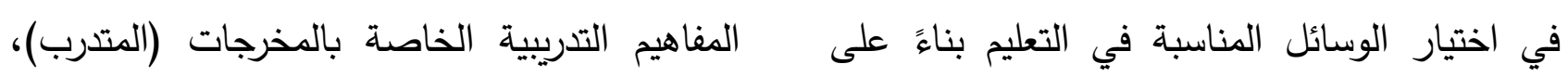

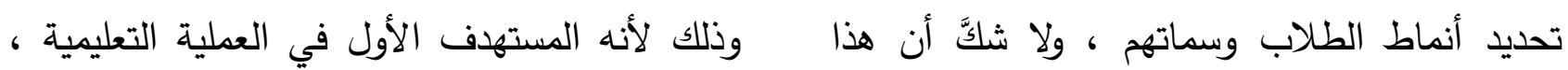

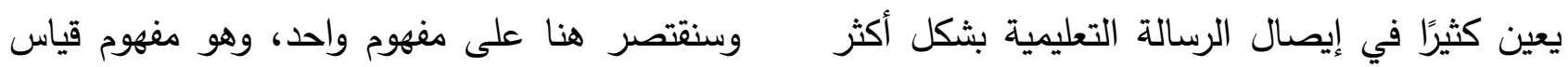

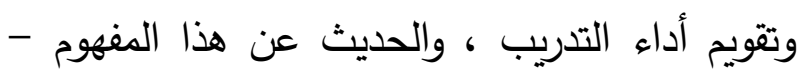
إنقانًا وأعظم أثرًا (') إنمئ

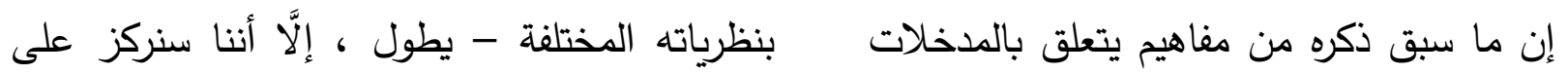

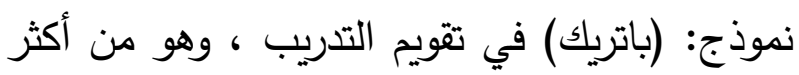




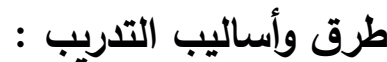

إذا نظرنا إلى التدريب على أنه فن من الفنون لارتباطه بالممارسة والتطبيق؛ فإن ذلك يستلزم

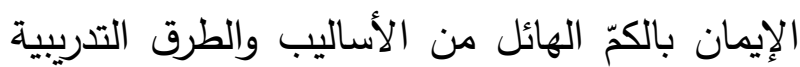
التي تتزايد وتتطور بتطور الحضارة الإنسانية

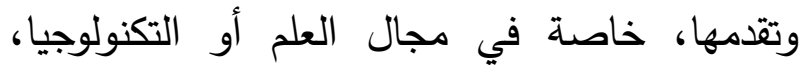
وتتوع هذه الأساليب معتمد على تتوع حاجات

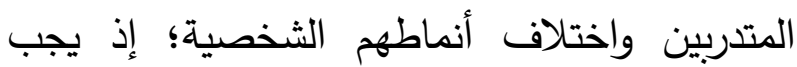

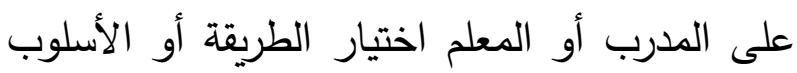
المناسب لكل موقف تدريبي وفق معايير عديدة منها احتياجات المتدربين، وحجم المتدربين، وأماكن تواجدهم، والإمكانات المالية، وعامل الزمن، والوقت

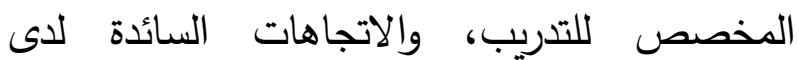
المتدربين، وغيرها من المعايير، كما أنه يمكن تصنيف هذه الطرق إلى قسمين ، القسم الأول: طرق من تدريب جماعية، والثاني: طرق تدريب فردية . والحديث عن هذه الطرق وتعريفها ومميزاتها،

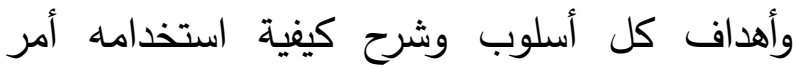
يطول، وليس هذا مجال بسطه وتفصيله، إلَّ أنه لا لا لهانه بد من الإشارة إلى بعض الطرق والأساليب التدريبية

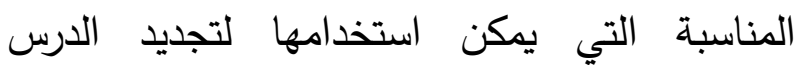
اللغوي، والتقليل من الاعتماد الكامل على أسلوب

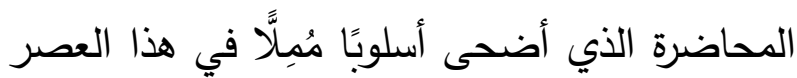
الذي اتسم بروح التفاعل والمشاركة والانفتاح •

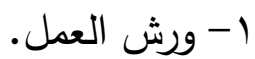

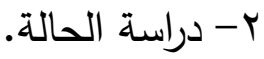

النماذج انتشارًا في المؤسسات عمومًا ، ويقوم هذا النموذج على تحديد أربعة مستويات للقياس والتقويم، وهي : 1- المستوى الأول: قياس رد الفعل للشخص . r- المستوى الثاني: قياس التعلم • التصن

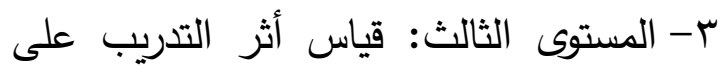
سلوك وأداء الثخص.

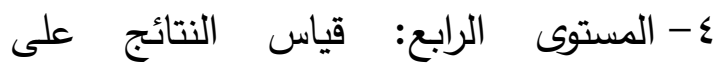
المؤسسات عمومًا. ويمكن استثمار هذا النموذج واستخدامه في تعليم اللغة العربية من حيث استخدام آلياته ووسائله في داخل المؤسسة التعليمية ، ويلاحظ على هذه الدقاييس شموليتها، وعدم اقتصارها على جانب المعرفة فقط؛ بل يتعدى ذلك إلى التطبيق والممارسة،

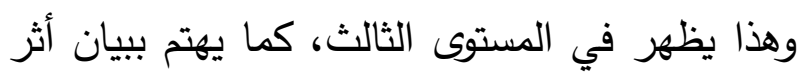
التعلم على الأداء العام من خلال تطبيق معايير المستوى الرابع ، وتعظم أهمية هذا المفهوم في مراكز تعليم اللغة العربية لغير الناطقين بها ؛ إذ لا بد من لهن

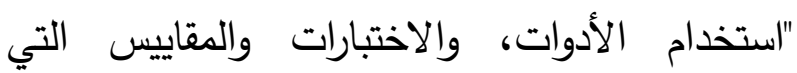
تساعد على التحديد الدقيق للحاجات اللغوية عند الدارسين، وأنماط التعلم السائدة بينهم، واستعداداتهم لتعلم اللغات الأجنبية، وتوقعاتهم منها، وغير ذلك من جوانب مؤشرات لازمة، تصمم في ضوئها برامج

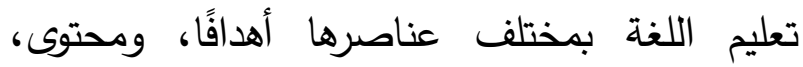
وطرق تدريس وتقويم (')". (1) ينظر تعليم اللغة العربية لغير الناطقين بها، د. رشدي طعيمة ص: • . 
1- تحويل المعارف والمعلومات التي درسها الطلاب خلال دراسته إلى مهارات وممارسات لغوية يطبقونها بكل كفاءة . r-تعويد الطالب على الجُرأة الأدبية بواسطة

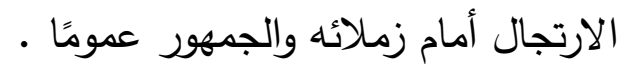

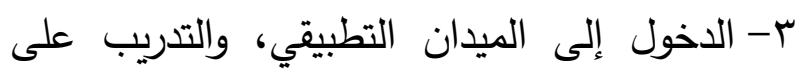
التعامل مع الواقع، وممارسة آليات ذلك من خلال

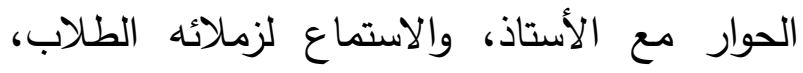
والإبانة عمّّا تعلمه ودرسه. ولتحقيق هذه الأهداف تم اختيار خمسة محاور لتكون مفردات المادة ، والتي سيجري تدريب الطلاب عليها، واختبارهم فيها ، وهي: 1- القرآن الكريم: وفي هذا المحور يحدد الأستاذ سورة من القرآن الكريم، ويطلب من الطالب حفظها ودراسة معاني المفردات من الناحية اللغوية، ومعرفة أوجه إعرابها، والأوجه البلاغية فيها، على أن يقوم

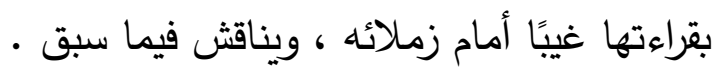
r- الثعر العربي: يختار الأستاذ قصيدة من عيون الشعر العربي، ثم يُلزم الطالب بحفظ مقطوعة من الن

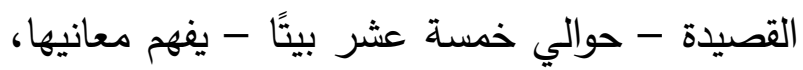
ويعرف وزن البحر ونوعه، ويعرب الألفاظ، على أن يُلقيها بطريقة إنشادية جيدة، ويسأل فيما سبق .

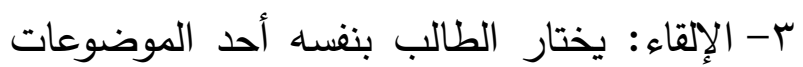

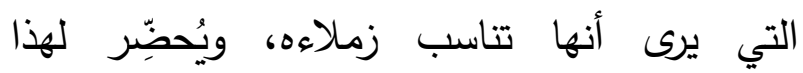
الموضوع من خلال القراءة، وإعداد الشواهد ، وتركيز الموضوع في نقاط محددة ، تظهر فيها براعة الطالب

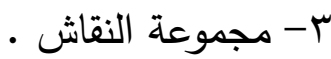

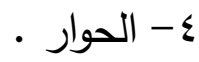

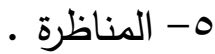

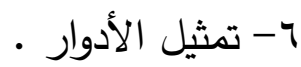

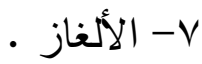

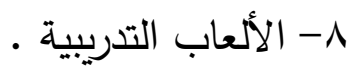

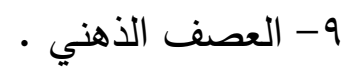
• الخرائط الذهنية .

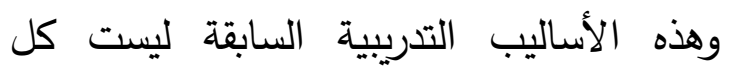
الأساليب ، إلَّا أنها من أهم الأساليب التي يمكن استخدامها في تعليم اللغة العربية ، وتشويق الطلاب وإمتاعهم للإفادة من درس العربية وعلومها المختلفة

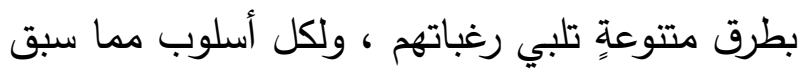

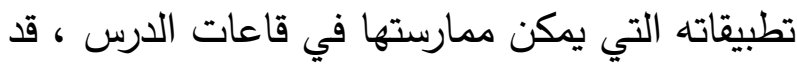
لا يكون هذا مجال بسط الكتابة فيها، وذكر صورها

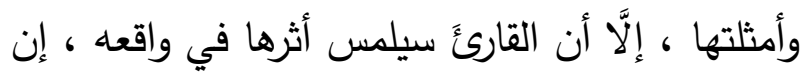

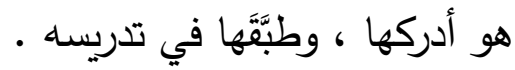
تجربة ذاتية :

أسنذَ إليَّ تدريس مادة جديه جديدة استحدثت في خطة قسم اللغة العربية بجامعة الملك عبد العزيز، لإنال وكانت بعنوان : (التدريب العملي) ، وكان الهدف لهُبه

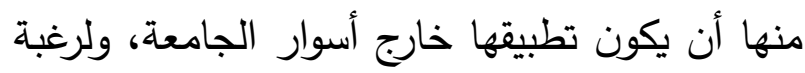
الجامعة في التأني في ممارستها خارج الجامعة خلا السنوات الثلاثة القادمة؛ فقد اجتهدتُ في بناء منهج لها في هذه الفترة الانتقالية، فوضعتُ أهداف المادة على النحو التالي: - الني: 
ويلاحظ تركيز هذه المحاور على المهارات اللغوية، وتعويد الطالب على التدريب عليها، وممارستها ، وقد تم وضع نماذج للتقويم على النحو

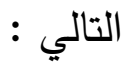

يقوَّم الطالب على المهارات السابقة على أن يراعي معايير التقويم في كل محور ، وهي موجودة في النماذج المرفقة ، وتكون موزعة على النحو

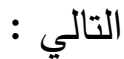

القرآن الكريم: ب ب درجة، الشعر العربي: درجة، الإلقاء: ·r درجة، القراءة الجهرية: 10 درجة، التتقيق اللغوي: 10 درجة . ويجب على الطالب اجتياز المحاور الخمسة كلها في الأوقات التي يحددها أستاذ المادة ـ
في الإلقاء خلال فترة محددة ، حوالي خمس دقائق،

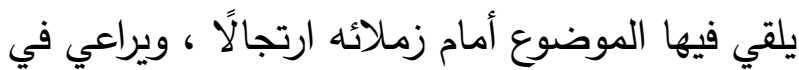
إلقائه سلامة النطق واللغة والإعراب الصحيح، وحسن الصوت بما يتاسب مع المقام • ع- القراءة الجهرية : يُعطى الطالب قطعة لغوية مستقلَّة من كتب العربية ، ويطلب منه قراءتها قراءة جهرية أمام زملائه ؛ بحيث يراعي فيها الالتزام بالقواعد الإعرابية، والوقف السليم، ومخارج الحروف. 0- التدقيق اللغوي : يُعطى الطالب نصَّا على أن يُصححه من الناحية اللغوية والإعرابية والإملائية ، ويُكلَّف الطالب بأن يضع على النَّص علامات الترقيم المناسبة ، مع حركات الإعراب ، وذلك لإبراز

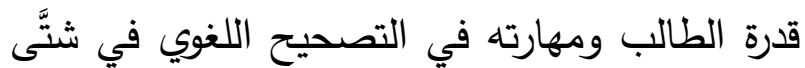

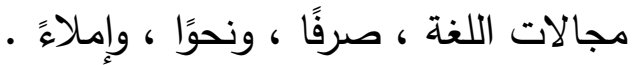

\section{نموذج تقويم القرآن الكريم :}

\begin{tabular}{|c|c|c|c|c|c|c|}
\hline المجموع & التجويد الأدساء & البلاغة & الإعر اب & المفرداتي & السورة حفظ & الطالب \\
\hline 0ب درجة & 0 درجات & 0 درجات & ه درجات & 0 درجات & 0 درجات & \\
\hline
\end{tabular}

نموذج تقويم الإلقاء الثعري :

\begin{tabular}{|c|c|c|c|c|c|}
\hline المجموع & الأداء ومهارة الألفاظ & الإعراب & المفرداتي & القصيدة حفظ & الطالب \\
\hline 0ب درجة & 0 درجات & 0 درجات & 0 درجات & • ا درجات & \\
\hline
\end{tabular}




$$
\text { نوح بن يحيى الثهري }
$$

\section{: نموذج تقويم إلقاء موضوع :}

\begin{tabular}{|c|c|c|c|c|c|}
\hline المجموع & (حسن الوقف وات الإلقاء & الإعرابة & سلامة اللغة & 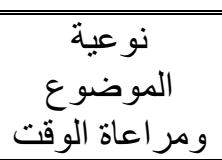 & الطالب \\
\hline •r درجة & 0 درجات & 0 درجات & 0 درجات & 0 درجات & \\
\hline
\end{tabular}

\section{نموذج تقويم القزاعة الجهرية :}

\begin{tabular}{|c|c|c|c|c|}
\hline المجموع & مهار ات القراءة & صحة الإعراب & سلامة اللغة & اسم الطالب \\
\hline 0 & 0 & 0 درجات & 0 درجات & \\
\hline
\end{tabular}

نموذج تقويم التدقيق اللغوي :

\begin{tabular}{|c|c|c|c|c|}
\hline المجموع & تصحيح الأخطاء & علامات الترقيم & ضبط الكلمات & سم الطالب \\
\hline 1 درجة & ه درجات & 0 درجات & ه درجات & \\
\hline
\end{tabular}

\section{نموذج التقويم النهائي :}

\begin{tabular}{|c|c|c|c|c|c|c|}
\hline المجموع & التدقيق & القر اءة & الإلقاء & القصيدة & الكريم & الطالب \\
\hline ·. . درجة & 0 ا درجة & هادرجة & • ب درجة & هץ درجة & هب درجة & \\
\hline
\end{tabular}

وقد كانت نتائج هذه التجربة مثيرة إيجابًا وسلبًا، ومن ودروسنا، وما ترك ذلك التقصير من الأثر السلبي ذلك أن أسلوب التدريب والتطبيق لم يعهده الطلاب في تكوين الطلاب الذين لا يكادون يقيمون جملة في مقاعد الدراسة ؛ بل إن كثيرًا منهم ذكر لي أنه لم التحيحة، كما لاحظتُ مدى التقدم والأثر الإيجابي يقف أمام زملائه منذ خمس سنوات، زمن دراسته على بعض الطلاب، وقدراتهم اللغوية ، وإفادتهم من الجامعية، وشعرتُ بالحزن والأسى على تقصيرنا أساليب التدريب المستخدمة في رفع العناية بالمهارات الكبير في عدم استخدامنا للتدريب في محاضراتتا اللغوية والتمرس عليها . 
• تأهيل معلمي اللغة العربية، ورفع كفاءتهم التدربية حتى يكونوا قادرين على تتمية المهارات اللغوية للطبلاب

• تحفيز الطلاب وتشجيعهم وترغيبهم في حب اللغة العربية وفنونها، حتى يقبلوا على دراستها وتعلمها والتدرب عليها . • تطوير أساليب التعليم وطرقه، وعدم الاقتصار على أسلوب المحاضرة، وذلك باستثمار أساليب

التدريب الحديثة وتطبيقها في تعلم العربية . ه العناية بالمهارات، وتوظيف كل برامج التعليم المختلفة لخدمتها، وعدم الاقتصار في التعليم على مهارتي الحفظ والتركيز ، وذلك بمراعاة تتمية مهارات التحليل والتركيب والاستتباط والتقويم والتطبيق لدى - الطلاب • إعادة كتابة مناهج اللغة العربية لتتوافق مع منهجية إعداد الحقائب التدريبية، وذلك لزيادة مستوى الاستيعاب لاى الطالب . • إقامة ورش عمل مختلفة في الجامعات ، تجمع المتخصصين في اللغة العربية للاطلاع على خبراتهم وتجاربهم في تدريس العربية واستثمار مثل هذه المؤتمرات في هذا الهدف . ه الاستفادة من الدراسات التربوية والتعليمية الحديثة سواء العربية منها والأجنبية في تطوير العمل على التدريب ، وتتميته في خدمة التعليم •

\section{الخاتمة}

وفي ختام هذه الدراسة يمكنني إجمال ما توصلت إليه من خلال البحث بما يلي: ( أهمية اللغة العربية ومكانتها في حياة المسلم؛ إذ إذ بواسطتها يفهم المسلم مراد الله عز وجل في كتابه ومراد نبيه بئس في السنة النبوية. r) أسباب ضعف تعليم اللغة العربية، وطرق علاج هذا الضعف. r) أن التعليم رسالة وليس صنعة. ع) جدوى التدرج في التعليم وأثره على إتقان مهارة

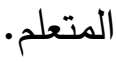
0) مفهوم التدريب وأهميته، وأساليبه، وطرقه، ودوره في تتمية المهارات اللغوية. 7) الفرق بين التدريب والتعليم. V نماذج من استخدام السلف الصالح للتريب في

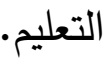
^) عرض تجربة الباحث في تدريس مادة (التدريب العملي) لطلاب جامعة الملك عبد العزيز ، وأهداف هذه المادة ومحاورها، وكيفية تقييم الطالب من خلال

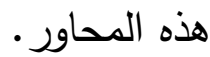

\section{التوصيات}

التأكيد على أهمية تداخل العلوم، واستثمارها لخدمة بعضها، وعدم الانحصار في زوايا محددة فقط . 
[^] تاريخ ابن خلدون = ديوان المبتدأ والخبر في

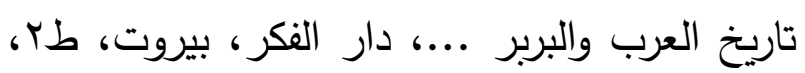
. [9] معجم المسائل النحوية والصرفية الواردة في القرآن الكريم، الدكتور ف. عبد الرحيم (فانيا مبادي

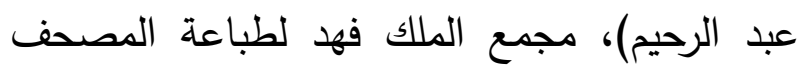

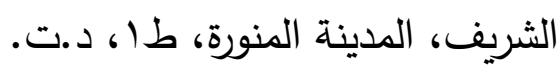
[ [ [] سنن أبي داود، المكتبة العصرية، صيدابيروت، تحقيق محمد محيي الدين عبد الحميد. [1 [ [ التوجيه الإسلامي للنمو الإنساني عند طلاب

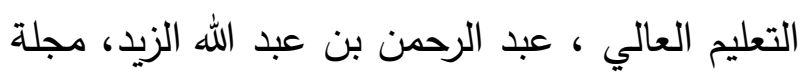

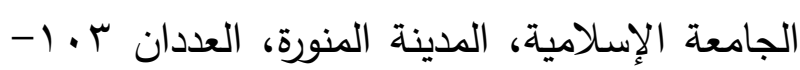

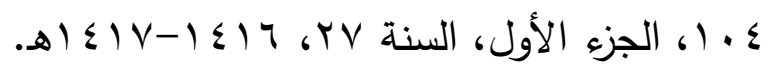
[Y I [ فن التحرير العربي ضوابطه وأنماطه، د. د. محمد صالح الثنطي، دار الأندلس للنشر، حائل، وائل،

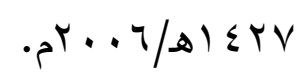

[1 I] تاج العروس من جواهر القاموس، محمد بن محمد المرتضى الزبيدي، دار الهداية، د.ت. [ 1 1] أمالي ابن الثجري، هبة الله بن علي ابن

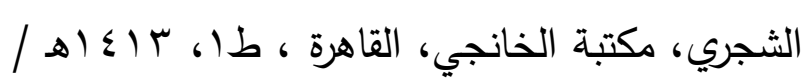
1991 ام، تحقيق : د محمود الطناحي . [10] البيان والتبيين، عمرو بن بحر الجاحظ، دار

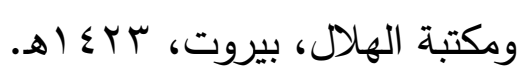

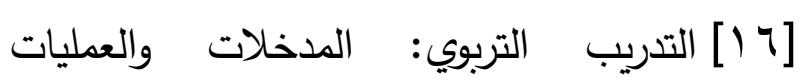
والمخرجات وقياس اتجاهات المستفيدين، د. صالح

\section{المراجع}

[1] مسند الإمام أحمد، مؤسسة الرسالة، بيروت،

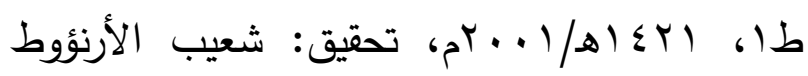
وغيره، إشراف: د. عبد الله التركي. [ץ] ندوة ظاهرة الضعف اللغوي التي أقامتها جامعة إنداه

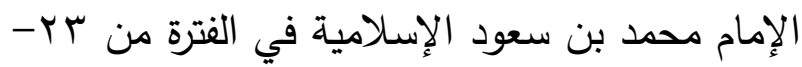

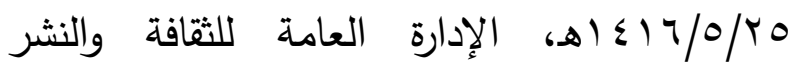

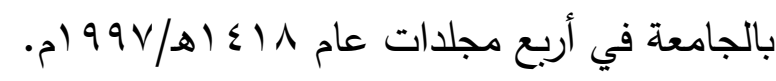
[r] محاضرة اتجاهات تعليم العربية في الأقسام الجامعية وممارسته، د سليمان العايد، وقد نثِر الجرات

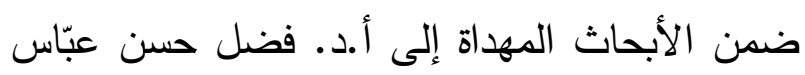

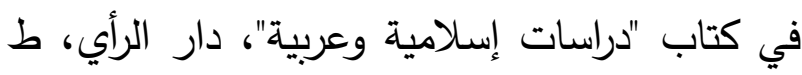

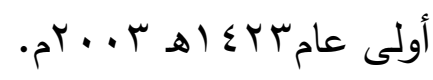
[§] القراءة الجهرية بين الواقع وما نتطلع إليه، د. سليمان العايد، بحث ضمن بحوث ندوة "ظاهرة الضعف اللغوي" التي أقامتها جامعة الإمام محمد بن بن لدان

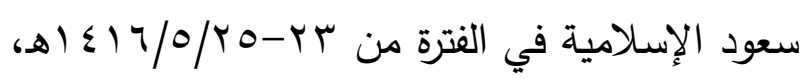

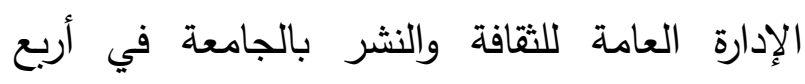

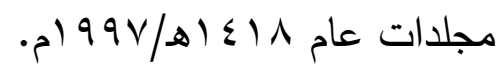
[0] أليس الصبح بقريب ، محمد الطاهر بن

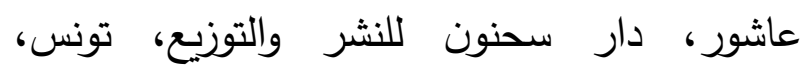

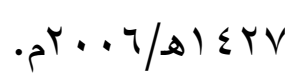
[7] التعليم: أسسه - مناهجه - نظرياته ، د. د. أحمد زكي صالح، مكتبة النهضة المصرية، القاهرة، د.ت. ع [V] [لم النفس والتعلم ، حسن حافظ وآخرون، مكتبة الانلجو المصرية، القاهرة، 901 ام. 
rا •rم، بتحقيق حيدر جبار عيدان وحسن عبد

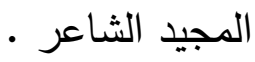

[Yo] بغية الوعاة في طبقات اللغويين والنحاة، عبد الرحمن بن أبي بكر السيوطي، المكتبة العصرية،

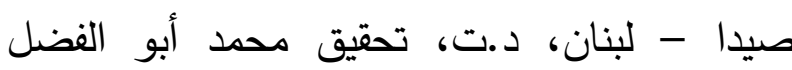

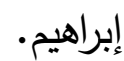

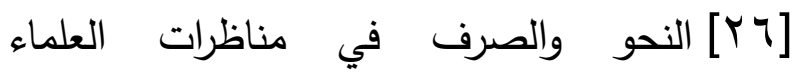
ومحاوراتهم، محمد آدم الزاكي، جامعة أم القرى، مكة المكرمة، 0. أهـ/910 ام. [rV] تعليم اللغة بين الواقع والطموح، د. محمود

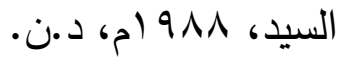
[Y^] تعليم اللغة العربية لغير الناطقين بها في في المجتمع المعاصر، اتجاهات جديدة وتطبيقات

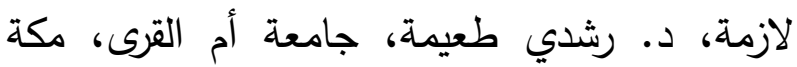

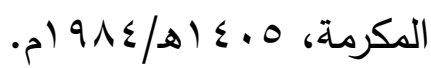
[Y9] فن الإلقاء، طه عبد الفتاح مقلد، مكتبة الفيصلية، مكة المكرمة، د.ت.

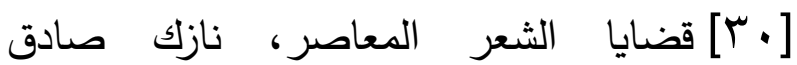
الملائكة، دار العلم للملايين، بيوت. [بr] النظرية اللغوية في التراث العربي، د. محمد

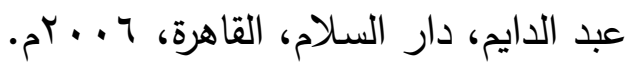
[Yr] المدخل إلى مذهب الإمام أحمد بن حنبل،

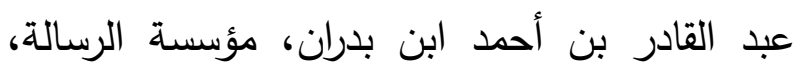
بيروت، طץ، 1 ـ ـ اهـ، تحقيق د. عبد الله التركي.

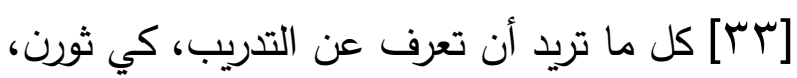

بن أحمد الطريقي، ابس؛ اهـ.

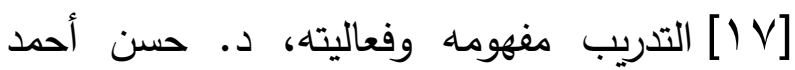

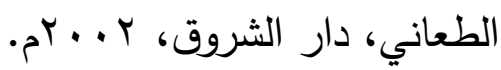
[111] العددة في محاسن الشعر وآدابه، الحسن بن

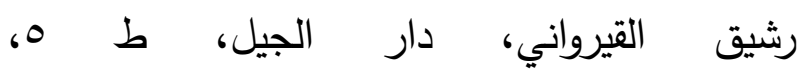
.

[9 1 ] التحليل النحوي أصوله وأدلته، د، فخر الدين

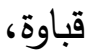
الثركة المصرية العالمية للنشر لونجمان، مصر،

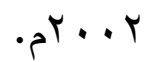
[?[?] الألغاز النحوية طبيعتها وقيمتها في التراث النحوي، د. سماسم بسيوني مطر ، بحث منشور في حولية كلية اللغة العربية بالمنوفية - مصر، العدد

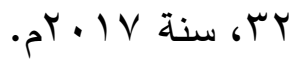
[Yl] ألغاز الحريري وأحاجيه في مقاماته، مكتبة ابن سينا، مصر ، تعليق محمد إبراهيم سليم. [YYT] الألغاز النحوية، عبد الله بن يوسف بن هشام

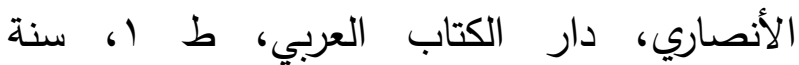

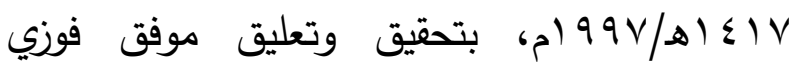

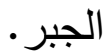

[YrT] الطراز في الألغاز، عبد الرحمن بن أبي بكر

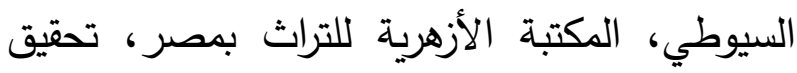
طه عبد الرؤوف سعد. [ـץ] الألغاز النحوية في علم العربية، خالد الأزهري بحث منشور في مجلة كلية التربية للبنات للعلوم الإنسانية بالكوفة، في العدد سا، السنة السابعة، 


$$
\text { الخبراتي ، أ/ ربيعة جعفور }
$$

https://revues.univ-ouargla.dz/index.php/numero-11ssh/1477-2013-06-10-15-18-22

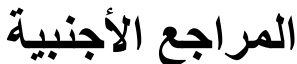

[1] Alice Y . Kolb \& David A. Kolb(2005): The Kolb Learning Style Inventory- Version 3.1Technical Specification.Case Western Reserve University May 15.2005

[2] Kristen

C.Schellhas(2006):Kolb's Experiential Learning Theory in Athletic Training
مركز الخبرات المهنية للإدارة، 999 ام.

[؟ [ب] مقالة : أساليب التعلّم مفهومها وأبعادها والعوامل المشكلة لها حسب نموذج كولب للتعلم

Education:A Literature Review. Athletic training education journal 2(apr- dec):18-27.

[3] Ponle Gideon Adetunji: AN EVALUATION OF DAVID KOLB'S THEORY OF LEARNING STYLES.the Nigerian Baptist theological

seminary'ogbomoso'oyostate.Ilorin Journal of Education. 


\title{
Training Concepts and Methods in Teaching Arabic Language
}

\author{
Dr. Noah ibn Yahya Alshehri \\ Arabic Language Department \\ Faculty Arts and Humanities \\ King Abdulaziz University, Jeddah
}

\begin{abstract}
In this research, this paper examines the concepts and methods of training which can be used in teaching Arabic language. It addresses the distinctive role of syntax in in having a functional role to develop language skills. Is also highlights the place of syntax between the message and the craftsmanship, shows the scale of training, and demonstrates the difference between training and education to show some of the examples of the the early scientists' usage of training methods. Moreover, It discusses training on language skills, citing experiment of teaching (Practical Training) for students of King Abdul Aziz University, and its objectives, topics, and outcome assessment. The paper is then concluded with some recommendations.
\end{abstract}

